\title{
The Costs of the Consensual Myth: Antitrust Enforcement and Institutional Barriers to Litigation in Japan
}

\author{
J. Mark Ramseyer $\dagger$
}

Even in the West, lawyers have never been loved. As Mozart blamed an attorney for plotting to prevent Figaro from marrying Susanna, so Orson Welles may have blamed the venerable $\mathrm{Mr}$. Thatcher for separating Charlie Kane from his Rosebud; indeed, Shakespeare would have executed the entire profession. ${ }^{1}$ Notwithstanding their alleged venality, lawyers in the West have done well for themselves. But in Japan, we are told, they have sunk to their proper station in life. Japan has become in the American imagination a place where lawyers are few, litigation is rare, and the bureaucracy governs by developing a national consensus. ${ }^{2}$ What the Japanese save on legal fees, they use to develop computers, video games, and Walkmans.

There are indeed few lawyers and lawsuits in Japan. This dearth has been a mixed blessing, however, for the scarcity of litigation has led to a substantial under-enforcement of the law. In antitrust, inadequate enforcement has resulted in price-fixing cartels and production restraints. This shortage of lawyers and litigation does not, as commentators have often suggested, result solely from a "nonlitigious" ethos. There may indeed be such an ethos, but it is an ethos buttressed by an array of institutional barriers to litigation that would discourage all but the most persistent plaintiffs in any society.

This Article approaches antitrust law as a case study in the role of litigation in Japan. It begins by summarizing the role of private litigation in deterring illegal behavior and describing the relation between cultural attitudes toward litigation and institutional barriers to the use of the

+ Associate, Sidley \& Austin, Chicago, Illinois. B.A. Goshen College, 1976; A.M. University of Michigan, 1978; J.D. Harvard University, 1982. I wish to thank James Egan, George Lane, Robert Ramseyer, John Roth, Priscilla Ryan, Frank Upham, and Norma Wyse for their generous comments on earlier versions of this article, and Hideko Maki for her kind bibliographic assistance.

1. Respectively, W. Mozart, Le Nozze di Figaro, Act III (1786); Citizen Kane (O. Welles dir. 1941); W. Shakespeare, The Second Part of Henry VI, Act IV, Sc. 2 (1623).

2. See, e.g., E. VoGel, JAPAN As Number ONE 53-64 (1979) (meritocratic bureaucracy governs through consensus); Lieberman, Confucius's Lesson to Litigants, N.Y. Times, July 9, 1984, at 19, col. 1 (praising Japanese emphasis on mediation); Land Without Lawyers, TIME, Aug. 1, 1983, at 64 (describing limited role of Japanese lawyers). 
courts. It then compares the American and Japanese frameworks for private antitrust litigation, and analyzes the various antitrust damage actions in Japan to date. After outlining the major institutional barriers to such suits, the Article discusses the implications of these barriers for the distribution of power and wealth in Japanese society. Specifically, it argues that the barriers have eliminated virtually all deterrents to cartelization in Japan. More generally, it suggests that the barriers to antitrust suits are but one example of barriers to litigation that have helped to reinforce a nonlitigious ethos and have thereby played an important part in assuring the continued legitimacy of bureaucratic rule.

\section{Private Damage Litigation}

Many of the misconceptions about Japanese litigation derive from two assumptions that most Americans bring to the subject: that money spent on private litigation is a net loss to society, and that the willingness of a Japanese to sue depends almost entirely on cultural norms regarding litigation. In fact, however, increased private litigation might well result in a net gain in social welfare, and the Japanese legal structure itself serves to perpetuate the well known cultural norms toward litigation.

\section{A. The Public Interest in Private Litigation}

Private litigation has long served a public purpose in the AngloAmerican tradition. Socially intolerable behavior often gives rise to both a criminal and a civil cause of action: If picking pockets has been a crime, it has also been a tort. Traditionally, however, the rationale for the two causes of action differed. The Crown hanged pickpockets for a public purpose-to stop pickpockets from stealing; the Crown let victims recover the value of their pocketbooks for a private purpose-to make victims "whole." Yet the line between deterrence and compensation has been far from clear. To the extent that the fear of hanging deters pickpockets, compensation becomes irrelevant. To the extent that a victim is likely to recover damages, the tort suit deters pocket-picking.

Deterrence is thus a function not of criminal penalties alone, but rather of the sum of all public and private sanctions. According to current theory, the optimal level of deterrence results when the burden to the wrong-doer of the sanctions for a given act equals the net harm which that act causes to other members of society, divided by the probability of the wrong-doer's apprehension and successful prosecution. ${ }^{3}$ Of course, considerations like

3. See, e.g., Becker \& Stigler, Law Enforcement, Malfeasance, and Compensation of Enforcers, 3 J. Legal STud. 1, 6-13 (1974) (describing model); Landes, Optimal Sanctions for Antitrust Violations, 50 U. ChI. L. Rev. 652, 653-657 (1983) (same); Page, Antitrust Damages and Economic 
optimality, the burden of a given sanction, and the harm of a given act often involve calculations not easily quantified in the real world. Whatever the difficulties of practical application, however, it is safe to say that smaller sanctions will in general fail to dissuade wrong-doers from engaging in conduct that creates a net loss to society, while larger sanctions may induce wrong-doers to refrain even from illegal behavior that confers a net benefit to society. ${ }^{4}$

To the extent that the state carries on prosecutorial activities at levels that produce less than optimal deterrence, private litigation takes on a public role. The prosecutor's office may be subject to budgetary restraints or may decide not to prosecute various crimes for ideological or political reasons that have nothing to do with the optimal level of law enforcement. ${ }^{5}$ This Article is not the place to discuss what the optimal level of law enforcement might be if the size of the sanctions could be varied-i.e., whether the probability of apprehension should be relatively low and the fine correspondingly high, or the probability of apprehension high and the fine low. ${ }^{8}$ Nevertheless, it should be clear that unless a society carries on sufficent enforcement activities to produce optimal deterrence without private litigation, it has a public interest in facilitating private litigation.?

Profit-maximizing victims of illegal behavior will sue, however, only when the amounts they may recover, multiplied by their probability of success, exceed their litigation costs. If various barriers to litigation raise the costs of litigation or make it unlikely that victims will recover the full amounts of their damages, fewer profit-maximizing victims will sue than would otherwise. Barriers to litigation can take many forms. They may increase the victim's litigation expenses, lower the amount of any damage award, reduce the probability that a victim will prevail in court, or, to the extent that they diminish the credibility of a victim's threat to sue, lower the amount of damages a victim will obtain through settlement. ${ }^{8}$ As a result, such barriers can dramatically reduce the role of private parties in deterring illegal activity.

Efficiency: An Approach to Antitrust Injury, 47 U. CHI. L. REv. 467, 472 (1980) (same).

4. See, e.g., Landes, supra note 3, at 655 (discussing over- and under-deterrence); Page, supra note 3 , at 472 (same).

5. But see Landes \& Posner, The Private Enforcement of Law, 4 J. Legal Stud. 1, 36-38 (1975) (arguing that budgetary constraints may tend to prevent over-enforcement).

6. See Becker, Crime and Punishment: An Economic Approach, 76 J. Pol. Econ. 169, 180-85 (1968) (detailing optimality conditions); Polinsky \& Shavell, The Optimal Tradeoff Between the Probability and Magnitude of Fines, 69 AM. ECON. REv. 880 (1979) (offering distinct model of optimality).

7. Moreover, even the goal of compensation-as opposed to deterrence-is in part a public goal.

8. See R. Posner, Economic Analysis of Law 447-48 (2d ed. 1977). 


\section{B. The Cultural Context of Private Litigation}

An inquiry into the role of private litigation in Japanese society cannot, however, proceed on such purely economic terms. Perhaps no concept permeates discussions of the Japanese legal system so deeply as the notion that Japanese do not sue because of a "nonlitigious ethos":? a supposedly widely shared and strongly held set of beliefs and attitudes that condemns recourse to courts as selfish and un-Japanese. Only by understanding this peculiarly Japanese aversion to suing, we are told, will we understand the functions that litigation serves in Japan.

\section{The Nonlitigious Ethos}

The genesis of this ethos is less than clear. Some American and Japanese commentators have explained the ethos as simply a result of the group- and duty-oriented character of Japanese culture. Unfortunately, this analysis is more than a bit circular: Explaining the way people act as a product of their culture while defining their culture as the way they have learned to act is not, as sociologist Talcott Parsons is said to have told generations of students, terribly informative. ${ }^{10}$

Other commentators have adopted a more functionalist approach and explained that Japanese live in a hierarchical and particularistic society that functions effectively only by maintaining a high degree of interpersonal "harmony."11 Litigation destroys that hierarchical and particularistic harmony, for the universalistic standards used by the courts and the clear allocation of rights among individuals undermine compromise and

9. For convenience, this essay uses the term "ethos" to refer both to the moral and affective aspects of a culture and to its cognitive aspects. One could analyze these two elements separately. Professor Clifford Geertz, for example, defines the former as "ethos" and the latter as "world view." C. Geertz, The Interpretation of Cultures 126-27 (1973). What this essay calls the "nonlitigious ethos" contains dimensions of both ethos and world view: A Japanese individual not only lives in a world in which to sue is to violate strongly held and widely shared norms, but also employs a cosmology in which the norms against litigation are essential to social stability and reflect a peculiarly "Japanese" personality. To so dichotomize ethos and world view would introduce a further dialectic in the analysis of Section I.B. As Geertz points out,

a group's ethos is rendered intellectually reasonable by being shown to represent a way of life ideally adapted to the actual state of affairs the world view describes, while the world view is rendered emotionally convincing by being presented as an image of an actual state of affairs peculiarly well-arranged to accommodate such a way of life.

Id. at $89-90$.

10. See id. at $249-50$.

11. Professor Takeyoshi Kawashima has been a pioneering authority on legal sociology in Japan, and one of the more articulate spokesmen of this thesis. See T. KAWASHIMA, NiHONJIN NO HŌSHIKI [The Legal Consciousness of the Japanese] (1967); Kawashima, Dispute Resolution in Contemporary Japan, in LAw IN JAPAN 41 (A. von Mehren ed. 1963); Kawashima, The Legal Consciousness of Contract in Japan, 7 L. JAPAN 1 (C. Stevens trans. 1974). For writings by other commentators, see Noda, Characteristics of Japanese Mentality, in ThE JAPANESE LeGal System 295 (H. Tanaka ed. 1976); Shapiro, Can the Japanese Lack of Litigiousness Continue, in LeGal AsPects of DoIng Business in JAPAN 1983, at 25 (E. Lincoln \& D. Rosenthal eds. 1983). 
consensus. Because Japanese individuals have internalized the need to promote group harmony, they choose conciliatory solutions whenever possible. They hold paramount, in other words, the stability of the relational networks within which they live. ${ }^{12}$

Whatever its initial appeal, even this latter analysis obscures more than it clarifies, for it "explains" a Japanese phenomenon on the basis of cultural peculiarities without tying those peculiarities to the institutional characteristics that enable them to persist. In American scholarship, the first systematic analysis of the relation between this "cultural" phenomenon and the institutional structure of the Japanese legal system appeared in an article by law professor John Haley. ${ }^{13}$ Haley notes that Japanese do in fact "use their courts less frequently than do Americans,"14 but argues that the frequency of litigation does not itself determine whether Japanese are "litigious." The concept of nonlitigiousness, he explains, is useful only if it refers to an aversion toward litigation so strong that it induces wouldbe plaintiffs "to reach negotiated or mediated settlements that do not reflect" the amounts they could recover by suing. ${ }^{15}$ Haley found no such willingness to settle for amounts smaller than the probable litigated outcome discounted by the costs and uncertainties of litigation. He found instead that Japanese litigants sue less frequently because it is simply less profitable to sue in Japan.

Research in Japan tends to support Haley's argument that the Japanese do not, as a rule, avoid litigation when litigation is financially advantageous. For example, several Japanese scholars have argued that Japanese individuals avoid litigation primarily because of its high costs in

12. One of the more fundamental weaknesses of this analysis is its ambition: It purports to define a "Japanese" culture and a "Japanese" reaction to differing modes of dispute resolution. However middle class and urbanized Japan may be, it is not a homogeneous society. Economic disparities, regional disparities, even substantial linguistic disparities remain. Nevertheless, this essay likewise assumes that an inquiry into the reaction of most Japanese to litigation can yield profitable generalizations about Japan as a whole.

13. Haley, The Myth of the Reluctant Litigant, 4 J. JAPANESE Stud. 359 (1978). The idea that disputants in some societies choose for cultural reasons to settle rather than litigate even when litigation would yield a more favorable net outcome (discounted by the various uncertainties involved) has been criticized in several ethnographic studies. See, e.g., J. Colliter, Law and Social. Change in Zinacantan 73, 252-53 (1973) (Mexico); M. Moser, Law and Social Change in a Ghinese Communrty 184 (1982) (Taiwan); Starr \& Yngvesson, Scarcity and Disputing: Zeroing-in on Compromise Decisions, 2 AM. ETHNologist 553, 554-60 (1975) (criticizing anthropological studies for undue Durkheimian bias toward harmony); $f f$. Tanner, Disputing and the Genesis of Legal Principles: Examples from Minangkabau, 26 Sw. J. ANTHROPOLOCY 375 (1970) (criticizing concept of law as institutionalization of central norms of society; law instead is often part of social change as disputants maneuver among various settlement and remedy options).

14. Haley, supra note 13 , at 362 . Note, however, that the American proclivity to sue has frequently been exaggerated. For example, only $2 \%$ of all automobile accident claims in the United States go to trial. R. POSNER, supra note 8 , at $434-35$.

15. Haley, supra note 13 , at 366 . 
money and delay and because of its cumbersome procedures. ${ }^{16}$ Public opinion surveys, although admittedly somewhat imprecise, support this argument. In one survey, when asked what factors would most strongly deter them from litigating a dispute, $64 \%$ of the respondents cited high litigation expenses, and $54 \%$ cited court delays-both factors that reflect dissatisfaction with the workings of the Japanese legal system rather than aversion to litigation generally. Only much smaller numbers of respondents cited factors that indicated a distaste for litigation: the clear-cut nature of judicial decisions, 26.3\%; the risk of an adverse decision, $10.6 \%$; the inaccuracy of judicial decisions, $9.4 \%$; or the damage to one's reputation from suing, $6.1 \% .^{17}$

\section{The Relation of the Ethos to Barriers to Litigation ${ }^{18}$}

If, as Haley argues, Japanese litigants refrain from litigating only when they perceive it to be financially advantageous to do so, then the accessibility of the courts becomes crucial to any discussion of the role of litigation in Japan. For if Haley is right, then use of the courts will depend primarily on the extent to which individuals think they can efficiently obtain redress through a suit. This perception, in turn, will depend on the existence of institutional barriers to litigation-factors that increase the costs of litigation, reduce the probability of a plaintiff's success, or decrease the amount of any damages a successful plaintiff might recover. Yet in both the United States and Japan, discussions of barriers to litigation have been scarce while discussions of the nonlitigious ethos have been legion.

Although this Article presents the two factors as separate and distinct, the nonlitigious ethos and the institutional barriers to litigation are mutually reinforcing rather than mutually exclusive. ${ }^{19}$ Substantial barriers to

16. See, e.g., Ishii, Nihon: Meiji izen [Pre-Meiji Japan], in HöhaKaigaku кōza [Symposium ON LEGAL SOCIOLOGY] 257, 258 (T. Kawashima ed. 1973).

17. When asked whether they would sue if they became involved in a controversy, $38.6 \%$ of the respondents replied that they would litigate, while $26.5 \%$ said they would not, and $31.6 \%$ were undecided. The replies cited in the text were given by the $26.5 \%$ who said they would not litigate. Ho, SAIBAN, Bengoshi [LAw, Litigation, LAwyers] 76-90 (Ōsaka Bengoshi Kai ed. 1977); see also Kawashima, The Status of the Individual in the Notion of Law, Right, and Social Order in Japan, in The Japanese Mind 262, 272-73 (C. Moore ed. 1967) (similar statistics).

18. This section borrows heavily from P. Berger \& T. Luckmann, The Social ConstrucTION of Reality (1966); Berger \& Pullberg, Reification and the Sociological Critique of Consciousness, 4 Hist. \& THeORY 196 (1965).

19. One might argue that if the Japanese were truly nonlitigious no barriers to litigation would be necessary-and that the existence of institutional barriers disproves the existence of any nonlitigious ethos. The barriers may simply reflect, however, the sanctity which the Japanese governing clite ascribe to the nonlitigious ethos. The severity of the sanctions that most societies impose for incest, for example, may reflect not the predilections of the members of those societies toward incest as much as the severity of the damage that those members believe incest does to the social fabric. But see S. Freud, Totem and Taboo 14-17, 119-125 (J. Strachey trans. 1950) (incest taboo may reflect 
litigation may easily coexist with an orthodox ethos that discourages recourse to litigation. The relationship between the barriers and the ethos in such a situation is, however, dialectical. A number of observers have noted one half of the dialectic: Institutional barriers to litigation reflect the cultural ethos against litigation. All too often, however, the same writers have failed to appreciate the significance of the other half: The ethos may persist in part because of those barriers to litigation, for the barriers may remove many of the financial incentives to sue.

The nonlitigious ethos in Japan contains both a normative and a descriptive component. To sue is both to commit an act against the common good and to behave contrary to the prevailing definition of the Japanese nature. A would-be litigant lives, in other words, in a world in which suing is wrong and un-Japanese. Only to varying degrees, of course, have Japanese internalized this ethical and descriptive formula. As a result, only as individuals conform their conduct to the formula and repeat it to others do they preserve its intellectually coercive power-its ability to define for others what is good and Japanese. As sociologists Peter Berger and Stanley Pullberg explain, the intellectual world in which one lives "remains real, in the sense of subjective plausibility . . . only as it is confirmed and re-confirmed . . by others."20

Barriers to litigation reinforce this nonlitigious ethos by reducing the financial incentives to heterodoxy. A would-be plaintiff in a case in which litigation offered a larger net recovery than extra-judicial avenues would choose between the security of the orthodox ethos and the financial rewards of taking his or her claims to court. If the nonlitigious ethos had a sufficiently precarious place in the Japanese intellectual universe, many Japanese in such a situation would pick the heretical alternative and sue. Such a result would not only create whatever instability litigation itself generates, but would also contribute to the breakdown of the universe in which litigation is unacceptable and un-Japanese: The larger the number of Japanese who went to court, the harder each individual would find it to believe that such conduct was unethical and to define a Japanese as one who does not sue. ${ }^{21}$ Institutional barriers to litigation prevent this result

predilections toward incest).

20. Berger \& Pullberg, supra note 18, at 201 (italics omitted).

21. Moreover, as recourse to courts becomes more common, the substantive rules of the extrajudicial fora will themselves change. As extra-judicial fora compete with the courts for clientele, the results offered by the extra-judicial fora will change to resemble more closely the results obtainable through litigation. If either litigant can coerce the other into using the courts, after all, an extrajudicial forum will continue in use only if both litigants believe it grants them at least as favorable a net recovery as litigation. See, e.g., M. Moser, supra note 13, at 180-81 (similar observation about rural Taiwan); Collier, Political Leadership and Legal Change in Zinacantan, 11 L. \& Soc'x Rev. 131, 132 (1976) (similar observation about rural Mexico); Haley, supra note 13, at 366 (Japan). 
by decreasing the number of situations in which litigation offers a larger net recovery than settlement.

Examined from this analytic perspective, Haley's article reveals the precarious nature of the nonlitigious ethos by showing its historically and culturally tenuous basis. Haley denies that any nonlitigious ethos that exists today is part of a long-standing historical tradition. Instead, he argues that it derives from a "conservative reaction to the rising tide of lawsuits in [the] 1920's and early 1930's and a concern on the part of the governing elite that litigation was destructive to a hierarchical social order . . . ."22 "The contemporary Japanese belief that they are a traditionally unlitigious people may reflect," Haley suggests, "a very successful transmission of values and perceptions by those in power in the immediate prewar years." 23 Demonstrating the fragility of the nonlitigious ethos, Haley's article implies that without institutional barriers the nonlitigious ethos would have little compelling power in itself. Without such barriers the ethos would lose much of its plausibility-and many Japanese would sue.

This Article examines antitrust damage actions as a case study in the role of litigation in Japanese society. Judging by the indifference of some Japanese commentators to cartels, ${ }^{24}$ one might argue that a case study in antitrust is inappropriate. After all, if most Japanese in fact consider antitrust violations harmless, Japan may well treat antitrust suits differently from other types of litigation. One can, however, easily exaggerate the alleged Japanese tolerance for cartels. ${ }^{25}$ When the public discovered an oil industry cartel in the early 1970's, for example, taxi drivers went on strike and housewives rioted. ${ }^{26}$ The outcry apparently even threatened to topple the Japanese government. ${ }^{27}$ The barriers to antitrust litigation are not unusual within the Japanese legal system, but rather are representa-

22. Haley, supre note 13 , at 373 .

23. Id. at 373 n.36.

24. See, e.g., T. IIDA, Nihonteki chikarazuyosa no saihakken [Rediscovering the DisTINCTIVE JAPANESE STRENGTH] 73-97 (1979) (summary of debate); Amaya, Wa no rinri to Dokkinho no rinri [The Ethics of Harmony and the Ethics of the Antimonopoly Act], BunGEI SHUNJU, Dec. 1980, at 176 [hereinafter cited as Amaya, Wa no rinri] (Ministry of International Trade and Industry (MITI) perspective); Amaya, Dokkinhō kaisei shian ni hanron suru [Opposing the Antimonopoly Act Revision Bill], Ekonomisuro, Nov. 17, 1974, at 36 [hereinafter cited as Amaya, Dokkinho] (same).

25. See, e.g., T. IIDA, supra note 24, at 73-97 (discussing Amaya thesis); Masamura, Dokkinho kaisei to "Nihon teki sangyo fudo" [Antimonopoly Act Revision and "the Peculiar Japanese Industrial Climate"], SHūkan Toyō keIZaI, Jan. 18, 1975, at 32 (same); Yasuda, Shirarezaru Dokkinhō to kimyo na giron [The Unknown Antimonopoly Act and the Strange Argument], Bunger sHuNJu, Jan. 1981, at 420 (same); Symposium, Fukyo taisaku to kyosos seisaku [Depression Policy and Competition Policy], 5 KeIzal hÖGAKKaI NENPO 93 (1984) (discussing impact of cartels on depressed industries).

26. See infra p. 619.

27. See Tsurumi, Japan, Daedalus, Fall 1975, at 113, 122. 
tive of barriers to litigation generally. Indeed, several recent studies suggest that barriers analogous to those described in this Article hinder such diverse forms of litigation as shareholder derivative suits, ${ }^{28}$ divorce actions, ${ }^{29}$ and environmental suits. ${ }^{30}$ Ultimately, antitrust may serve not just as a case study, but as an appropriate metaphor for the concentration of power in Japanese society-for the full impact of the barriers to antitrust and other litigation extends beyond the role such barriers play in preserving the concentration of economic power, to the role they play in legitimating and thereby perpetuating the concentration of political power in Japan.

\section{Antitrust Damage Suits: The Cases}

Gartels produce much the same results in Japan as in the United States. Some commentators, of course, have claimed that the peculiarities of Japanese culture transform cartels into a social benefit. ${ }^{31}$ The Japanese economy, they argue, is a more "cooperative" endeavor than Western economies, and cartels merely express this Japanese proclivity for cooperation. Yet an economy is an economy, whether individuals act on oriental or occidental avarice. An effective price-fixing arrangement necessarily produces the same results in Japan as elsewhere: It transfers wealth from purchasers to sellers, increases the price of the cartelized good above its marginal cost while decreasing its supply and increasing the demand for its substitutes, and increases the cost of producing the cartelized good. ${ }^{\mathbf{3 2}}$ The arrangement benefits society only if society at large benefits from such transfers of wealth and deviations from the competitive norm. Government-planned cartels aside, ${ }^{33}$ Japanese cartels are more likely than

28. See Tanaka \& Takeuchi, The Role of Private Persons in the Enforcement of Law: A Comparative Study of Japanese and American Law, 7 L. JAPAN 34, 41, 43 (1974).

29. See T. Bryant, Mediation of Divorce and Related Disputes in the Japanese Family Court System, with Emphasis on the Tokyo Family Court (U.C.L.A. Ph.D. dissertation 1984).

30. See Upham, After Minamata: Current Prospects and Problems in Japanese Environmental Litigation, 8 Ecology L.Q. 213 (1979).

31. See, e.g., Amaya, Wa no rinri, supra note 24, at 176 (cartels benefit Japan); Amaya, Dokkinhō, supra note 24 (same); cf. E. HADLEY, ANTITRUST IN JAPAN 372 (1970) (Western aversion to cartels not shared in Japan).

32. Cartels earn rents, decrease allocative efficiency, and decrease technical efficiency. See 2 P. Areeda \& D. Turner, Antitrust Law IT 402b, 405c (1978); Caves \& Uekusa, Industrial Organization, in Asia's New Giant 459, 490-508 (H. Patrick \& H. Rosovsky eds. 1976).

33. Some commentators have argued that the Japanese government has been astute enough to create cartels that do promote the general welfare. See Boston Consulting Group, JAPAN IN 1980 , at 32-33 (1974); I. Magaziner \& T. Hout, Japanese Industrial Policy 52 (1980); $c f$. C. Johnson, MITI and THE JaPANESE MiRaCle 17-34 (1982) (defending MITI's role in economy); E. VoGel, supra note 2, at 70-78 (same). This essay does not discuss whether the Japanese government-or indeed any government-could benefit society at large through cartels. See Note, Trustbusting in Japan: Cartels and Government-Business Cooperation, 94 HaRv. L. Rev. 1064, 1073 n.42 (1981) (citing various critiques of cartel-oriented policy of Japanese government). Although this essay analyzes the oil cartel cases in which the government did play a part, the thesis of this essay is based 
Western cartels to benefit society only if Japanese price-fixers as a group are singularly likely to form cartels that produce socially beneficial transfers and deviations-scarcely a plausible proposition.

In many ways, the Japanese Antimonopoly $\mathrm{Act}^{34}$ reflects this fundamental mistrust of cartels. Drafted under the supervision of American authorities in 1947, the Act reflects American economic theory of the time and prohibits most acts illegal under American antitrust law. ${ }^{35}$ At the point of enforcement, however, American and Japanese antitrust policies sharply diverge.

\section{A. The Framework for Antitrust Enforcement}

\section{United States}

American antitrust enforcement involves a combination of public and private litigation. Both the U.S. government and private parties can sue for equitable relief. ${ }^{36}$ The government can also sue for criminal sanctions, ${ }^{37}$ and private parties can sue for treble damages ${ }^{38}$ and collect attorneys' fees if they win. ${ }^{39}$

Within this framework, private damage actions have played a crucial role. Because criminal sanctions have been relatively light and haphazardly applied, and because equitable suits only minimally deter pricefixing, ${ }^{40}$ the private damage action has become the primary deterrent to cartelization. ${ }^{41}$ The possibility of a damage action deters a would-be price-fixer by reducing the price-fixer's anticipated payoff by the size of

on the need to deter seller-initiated cartels rather than government-sponsored cartels.

34. Shiteki dokusen no kinshi oyobi kōsei torihiki no kakuho ni kansuru hōritsu [Law Concerning the Prohibition of Private Monopolies and the Maintenance of Fair Trade], Law No. 54 of 1947, translated in H. TyoRI \& A. Uesugi, The ANTIMonopoly LAws of JAPAN 213-64 (1983) [hereinafter cited as Antimonopoly Act]. See generally Note, supra note 33, at 1064-73 (discussion of Antimonopoly Act).

35. See generally E. HADlEY, supra note 31, at 121-24 (discussion of 1947 act); H. IYORI \& A. Uesugr, supra note 34, at 10-13 (same); Kanazawa, The Regulation of Corporate Enterprise: The Law of Unfair Competition and the Control of Monopoly Power, in LAW IN JAPAN, supra note 11, at 480, 484-87 (same). Many of the more stringent provisions of the 1947 version of the Antimonopoly Act, however, were deleted or amended in 1953. Law No. 259 of 1953. For a general discussion of the 1953 amendments, see K. Yamamura, Economic Policy in Postwar Japan 56-61 (1967); Note, supra note 33 , at $1065-73$.

36. See Sherman Act $\S 4,15$ U.S.C. $\$ 4$ (1982); Clayton Act $\S \S 15,16,15$ U.S.C. $\S 26$ (1982).

37. See Sherman Act $\S 1,15$ U.S.C. $\S 1$ (1982). The government may also bring a damage suit on its own behalf. See 15 U.S.C. $\$ 15 a$ (1982).

38. See Clayton Act $\S 4,15$ U.S.C. $\S 15$ (1982).

39. See id.

40. Equitable sanctions fail to deter price-fixing because they simply halt illegal activities and do not cut into profits already made.

41. See Block, Nold \& Sidak, The Deterrent Effect of Antitrust Enforcement, 89 J. PoL. EcoN. 429, 431 \& n.3, 443-44 (1981). The Department of Justice initiates criminal prosecution only in cases of "undisputed illegality." See P. AREedA, Antrtrust ANalysis Il 152 (3d ed. 1981). 
the potential liability, multiplied by the probability that the victim will successfully recover. Because the probability of discovery generally increases with the magnitude of the collusive price markup, the availability of the damage action also lowers the amount by which price-fixers will raise their prices. The threat of a damage action, in other words, reduces the size of the most profitable price markup. ${ }^{42}$

Because damages from a cartel are often widely dispersed, and the cost of litigating an antitrust claim is high, American law permits class actions and parens patriae suits. ${ }^{43}$ These measures allow potential plaintiffs to pool their litigation costs when private suits would otherwise be unprofitable. ${ }^{44}$ Were it not for these procedural devices, plaintiffs in many sectors of the economy would conclude that litigation was simply not worth the cost. $^{45}$ In those sectors, the deterrent to price-fixing would virtually disappear. ${ }^{46}$

American law also attempts to increase the deterrent value of damage actions in situations where one victim "passes on" some of the cartel's damage to other parties. A company that buys a product whose price was fixed and then either sells that product to others or incorporates that product into goods it sells will generally "pass on" part of the price increase to its buyers. ${ }^{47}$ As a result, the damages from the cartel will be widely dispersed through the various levels of the distribution chain. Because the extent of the "pass on" will depend on elasticities of supply and demand, the ultimate incidence of the price increase will be extremely hard to

42. For an algebraic demonstration of this principle, see Block, Nold \& Sidak, supra note 41, at 430-33.

43. See FED. R. Crv. P. 23 (class actions); 15 U.S.C. $\$ 15 \mathrm{c}$ (1982) (parens patriae suits). The deterrent effects of these two remedies differ little.

44. Plaintiffs may also pool their resources by using collateral estoppel offensively. See, e.g., Parklane Hosiery Co. v. Shore, 439 U.S. 322 (1979) (stockholders permitted to invoke collateral estoppel because of previous S.E.C. litigation); Blonder-Tongue Laboratories, Inc. v. Univ. of Ill. Found., 402 U.S. 313 (1971) (determination of patent invalidity gives rise to estoppel claim). Congress has amended $\S 5$ (a) of the Clayton Act, 15 U.S.C. $\S 16(a)$ (1982), to make clear that collateral estoppel applies in antitrust actions to the extent it applies elsewhere.

45. To decide whether to litigate a case, potential antitrust plaintiffs necessarily compare the amount of their claim, multiplied by the probability of success, against their attorneys' fees, multiplied by the probability of failure. Plaintiffs discount their probable attorneys' fees because they may collect attorneys' fees if they successfully prosecute their suit. See 15 U.S.C. $\S 15$ (1982). Note, of course, that a court may decide not to award successful plainiffs the entire amount of their actual fees.

46. After conducting an empirical investigation of the bread industry, for example, Block, Nold, \& Sidak conclude that "only after class actions became a credible private remedy did the Antitrust Division's enforcement capacity or its filing of a bread price-fixing case deter collusion ...." Block, Nold \& Sidak, supra note 41 , at 444.

47. Buyers will "pass on" a portion of their costs unless the market for their product is one in which supply is perfectly inelastic or demand is perfectly elastic. For a diagrammatic illustration of this principle, see Harris \& Sullivan, Passing on the Monopoly Overcharge: A Comprehensive Policy Analysis, 128 U. PA. L. REv. 269, 284 (1979). 
prove. This difficulty will in turn dissuade victims of a price-fixing arrangement from suing. ${ }^{48}$

To deal with this "pass on" problem, American courts have adopted what has become known as the Illinois Brick-Hanover Sho $e^{49}$ rule. Under this rule, courts allow only the party who directly dealt with the pricefixer to sue, but to sue for the entire amount of the illegal markup. Although the rule deprives indirect purchasers of a cause of action, ${ }^{50}$ it increases the direct purchasers' recoveries while reducing their litigation costs. Because a direct purchaser will likely have better access to the information necessary to prove the antitrust violation than will an indirect purchaser, ${ }^{\text {bI }}$ the rule transfers the cause of action to the party generally best. able to litigate successfully. In so doing, it increases the deterrent value of private damage litigation even though it decreases the number of parties able to sue. ${ }^{\mathrm{b} 2}$

This framework for antitrust enforcement has not, of course, proven entirely satisfactory. The penalty under the American framework bears no resemblance to the optimal antitrust penalty, which would equal the net economic harm of the cartel to others, including the loss to those not purchasing a product because of the higher price, ${ }^{\mathbf{6 3}}$ divided by the probability of discovery. Perhaps because such a penalty would be too hard to administer, the American framework allows plaintiffs to sue for three times the gross overcharge, plus attorneys' fees, and then adds criminal sanctions. The overcharge is not the primary economic harm of the cartel, however, for it excludes the loss to those who decided not to purchase a given product because of the increased price. The multiplier of three may be appropriate for some activities, but will be too high for easily detected arrangements and too low for others. ${ }^{54}$ And the system fails to

48. The difficulty of proof increases litigation costs and decreases the probability of successful recovery.

49. Illinois Brick Co. v. Illinois, 431 U.S. 720 (1977); Hanover Shoe, Inc. v. United Shoe Mach., 392 U.S. 481 (1968).

50. Nevertheless, to the extent that direct purchasers realize that their sellers are charging an illegal price and anticipate recovering that overcharge, the true marginal cost of the good to the direct purchasers will be lower-for, in calculating their costs, the purchasers will discount the amount they pay by the amount they expect to recover in later litigation. Economic theory suggests that the direct purchasers will make their pricing decisions on the basis of this adjusted marginal cost. To the extent that they do so, the Illinois Brick-Hanover Shoe rule will result in lower prices to indirect purchasers. See Landes \& Posner, Should Indirect Purchasers Have Standing to Sue under the Antitrust Laws? An Economic Analysis of the Rule of Illinois Brick, 46 U. CHI. L. REv. 602, 605-06 (1979) (indirect purchasers are compensated for antitrust injury through lower prices). But see Harris \& Sullivan, supra note 47, at 298-99 n.67 (Illinois Brick rule leads to lower fixed costs, a windfall that does not necessarily translate into lower prices).

51. See Landes \& Posner, supra note 50, at 609-15.

52. For empirical evidence of this proposition, see id. at 625-34.

53. This is the "deadweight loss." See Landes, supra note 3, at 653-57.

54. Cf. R. Posner, Antitrust LAw 226 (1976) ("many antitrust violations are so difficult to conceal that the probability of detection is much greater than one-third"). 
coordinate public and private sanctions, even though the appropriateness of the sanctions levied depends on the sum of all public and private penalties actually imposed. ${ }^{\mathrm{ss}}$

\section{Japan}

Although the Japanese Antimonopoly Act created a Fair Trade Commission (FTC) as an analogue to the Federal Trade Commission and gave it the power to enforce the Act through criminal and civil sanctions, ${ }^{56}$ Japanese and American antitrust enforcement could hardly differ more. While the Antimonopoly Act does provide prison terms for price-fixers, ${ }^{87}$ it permits fines of only up to $\$ 23,000,{ }^{88}$ and its civil penalties include only consent decrees, ${ }^{80}$ cease-and-desist orders, ${ }^{60}$ and a surcharge of 0.5 to 2 per cent of a cartel's gross earnings. ${ }^{61}$ Although the FTC does initiate a fair number of administrative actions each year to which it generally obtains consent decrees ${ }^{\mathbf{2}}$ and although it regularly sues to recover the surcharge, ${ }^{63}$ neither a consent decree nor the surcharge can significantly deter price-fixing. ${ }^{64}$ Nevertheless, public antitrust enforcement has proceeded no further. The FTC has initiated only six criminal prosecutions in the thirty-seven-year history of the Antimonopoly Act, only two against cartels. $^{\text {Bs }}$

55. See Dam, Class Actions: Efficiency, Compensation, Deterrence, and Conflict of Interest, $4 \mathrm{~J}$.

LEGAL STUD. 47, 66-67 (1975).

56. See Antimonopoly Act, supra note $34, \S \S 27,45-70$.

57. See id. §§ 89-91.

58. See id. $\S 89(5,000,000$ yen). Prior to 1977 , the maximum fine was one tenth this amount. See Note, supra note 33, at 1082.

59. See Antimonopoly Act, supra note $34, \S \S 48,53-3$.

60. See id. $\$ 54$.

61. See $i d$. $\$ 7-2$. This provision has been available only since 1977 . See Note, supra note 33 , at 1081-82.

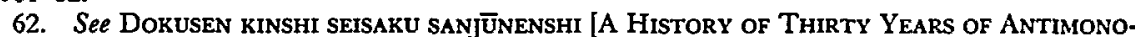
POLY PoltCY] 656-57 (Kōsei Torihiki Iinkai Jimukyoku ed. 1977) (collection of quantitative data) [hereinafter cited as SANJŪNENSHI].

63. See Motonaga, Kachōkin seido no genjo to toko [The Status and Direction of the Surcharge System], 751 JuRIsUTo 43, 46 (1981) (quantitative data).

64. See infra pp. 636-37.

65. See Japan v. Idemitsu Kōsan, K.K., 985 Hanrei jihō 3 (Tokyo High Ct., Sept. 26, 1980), translated in Ramseyer, The Oil Cartel Criminal Cases: Translations and Postscript, 15 L. JAPAN 57, 66 (1982), affd in part and rev'd in part, 1108 Hanrei jihō 3 (Japan Sup. Ct., Feb. 24, 1984); Japan v. Sekiyu Renmei, 983 Hanrei jihō 22 (Tokyo High Ct., Sept. 26, 1980), translated in Ramseyer, supra, at 57; Japan v. K.K. Miai Tōchi, unreported case (Tokyo High Ct., Jan. 29, 1971); Japan v. Ōkawa Gōmei Kaisha, unreported case dismissed under amnesty proclaimed with the U.S.Japan Peace Treaty (Tokyo High Ct., May 12, 1952); Japan v. Yamaichi Shōken, K.K., unreported case, prosecution withdrawn (Tokyo High Ct., Dec. 28, 1951); Japan v. Norin Renraku Kyogikai, unreported case (Tokyo High Ct. April 27, 1951), affd, unreported, (Japan Sup. Ct., Dec. 5, 1961). For citation to these cases, see SANjunENSHI, supra note 62, at 734; Ariga \& Rieke, The Antimonopoly Law of Japan and Its Enforcement, 39 WASH. L. REv. 437, 477 \& n.170 (1964); Kanazawa, supra note 35, at 486 n.51. Cartels were involved only in Sekiyu Renmei and Idemitsu Kosan. See SANJŪNENSHI, supra note 62, at 734. There have been no criminal prosecutions filed under the Antimonopoly Act since 1974. 
If public antitrust enforcement has been sparse, private antitrust enforcement has been almost nonexistent. Although the Antimonopoly Act grants the victims of a cartel a strict liability cause of action for actual damages, ${ }^{66}$ the private damage actions brought to date demonstrate the extent to which private Japanese antitrust litigation is a fiction. Private parties apparently have filed only seven antitrust damage suits. The plaintiffs in two of these cases settled; all others lost. ${ }^{67}$ Other than the plaintiffs who settled, ${ }^{68}$ no plaintiff collected any compensation. No private antitrust damage claimant has ever prevailed in court in Japan.

In two of the five private damage actions decided by a court, the FTC had not undertaken administrative actions against the defendants. ${ }^{69} \mathrm{Al}-$

By contrast, from 1945 to 1969 , the U.S. Department of Justice filed criminal prosecutions in over 350 cases. See Posner, A Statistical Study of Antitrust Enforcement, 13 J.L. \& EcoN. 365, 385 (1970).

66. See Antimonopoly Act, supra note 34, § 25. For a discussion of attorneys' fees, see infra notes $171 \& 185$.

67. There is, of course, no official count of the number of private antitrust actions filed. See Kai v. Nippon Sekiyu, K.K., 1005 Hanrei jihō 32 (Tokyo High Ct., July 17, 1981); Ōkawa v. Matsushita Denki Sangyō, K.K., 863 Hanrei jihō 20 (Tokyo High Ct., Sept. 19, 1977); Katō v. Kansai Surippa Seizō, K.K., 17 Kōsei Torihiki linkai shinketsu shū 269 (Tokyo High Ct., Nov. 24, 1958), affd, 17 Kōsei Torihiki linkai shinketsu shū 274 (Japan Sup. Ct., Sept. 27, 1960); K.K. Kosaka Yakkyoku v. Taishō Seiyaku, K.K., 9 Kösei Torihiki linkai shinketsu shū 162 (Tokyo High Ct., Feb. 19, 1958) (damages paid in out-of-court settlement); Satō v. Sekiyu Renmei, 997 Hanrei jihō 18 (Yamagata Dist. Ct., Mar. 31, 1981); Kyōei Dennetsu Kōgyō v. Okabe Maika Kōgyōsha, 53 Bessatsu jurisuto 231, 283 Hanrei taimuzu 324 (Osaka Dist. Ct., June 23, 1972); Takeuchi v. Nippon Sekiyu, K.K., unreported case settled out of court, discussed in Toyu saiban nigai wakai [Bitter Settlement in Kerosene Trial], Asahi shimbun, July 3, 1981, at 24. See generally Ariga \& Rieke, supra note 65, at 477 \& n.167 (noting one out-of-court settlement); Kanazawa, supra note 35, at 487 n.54 (same); Miyamoto, Dokkinhō to shōhisha-toyu saiban o megutte [The Antimonopoly Act and Consumers: Examining the Kerosene Trial], HorITsu JiHo, Sept. 1977, at 78, 79 \& n.4; Negishi, Sekiyu karuteru shohisha songai baisho seikyü jiken Yamagata chisai hanketsu [The Yamagata District Court Decision in the Oil Cartel Consumers' Damages Case], 741 Junisuro 94, 94 (1981); Tanaka \& Takeuchi, supra note 28 , at 37 n.10 (1974).

Kai and Sato have been appealed. See Suzuki, Keizaiho [Economic Law], Hōrrsu jı̄o, Jan. 1982 , at 119 .

68. K.K. Kosaka Yakkyoku v. Taishō Seiyaku, K.K., 9 Kōsei Torihiki Iinkai shinketsu shū 162 (Tokyo High Ct., Feb. 19, 1958); Takeuchi v. Nippon Sekiyu, K.K., unreported case settled out of court, discussed in Toyu saiban nigai wakai, supra note 67, at 23 . The plaintiffs in Takeuchi recovered 4,000,000 yen in attorneys' fees and an additional 5,000,000 yen for a legal aid agency. See Toyu saiban nigai wakai, supra note 67 , at 23 .

69. Kyōei Dennetsu Kōgyō v. Okabe Maika Kōgyōsha, 53 Bessatsu jurisuto 231, 283 Hanrei TAImuzu 324; Katō v. Kansai Surippa Seizō, K.K., 17 Kōsei Torhiki linkai shinketsu shū 162. Neither of these decisions is entirely satisfactory. As explained infra, pp. 623-24, an antitrust violation is also a compensable tort under Minpō (Civil CoDE), Law No. 89 of 1896, $\$ 709$, translated in 4 Codes and Statutes of Japan: The Civil Code (1949), and a $\$ 709$ suit need not follow an FTC decision. The plaintiffs in Kansai Surippa apparently did not specify whether they were suing under Antimonopoly Act $\S 25$ or MiNPō $\S 709$, but they did sue in Tokyo High Court-which has original jurisdiction over $\S 25$ suits but not $\S 709$ suits. See Antimonopoly Act, supra note $34, \S 85$ (ii). Thus, if the plaintiffs did not have a $\$ 25$ claim, the court arguably should have removed the case to a district court to hear the potential $\S 709$ claim. See MiNJı SOSHō hō (COdE of CiviL. Procedure), Law No. 29 of 1890 , translated in The [Japanese] Code of Givil Procedure $\$ 30$ (1950).

On the other hand, the plaintiff in Kyöei Dennetsu sued in the Osaka District Court, which has jurisdiction over a $\S 709$ but not a $\S 25$ claim. Without considering whether the plaintiffs had a $\S 709$ claim, however, the court dismissed the suit on the grounds that a $\$ 25$ claim does not lie where the 
though the Antimonopoly Act authorizes private actions, ${ }^{70}$ a plaintiff may sue under the Act only if the FTC has issued a final administrative order against the defendant. ${ }^{71}$ In neither of these cases had the FTC issued a final order. Thus, the courts faced the issue of antitrust liability only in three cases: Kai v. Nippon Sekiyu, K.K., ${ }^{72}$ Sato v. Sekiyu Renmei, ${ }^{73}$ and Okawa v. Miatsushita Denki Sangȳ, K.K. ${ }^{74}$

\section{B. Kai v. Nippon Sekiyu, K.K.}

Kai involved a kerosene price-fixing cartel. Fourteen distributors had controlled the entire kerosene market in Japan in the early 1970's. ${ }^{75}$ Twelve of the fourteen met secretly to try to raise prices, while the other two distributors, the Exxon and Mobil distribution subsidiaries, excused themselves from the meetings to protect themselves from American antitrust sanctions. ${ }^{76}$ Because the Exxon and Mobil subsidiaries followed the cartel's pricing policies even though they did not attend the meetings, ${ }^{77}$ the cartel seemed likely to succeed. The distributors reinforced their scheme by restricting refining operations through their trade association. ${ }^{78}$ And, as if to obtain legal sanction for their plans, they consulted repeatedly with the powerful Ministry of International Trade and Industry (MITI) and obtained its acquiescence. ${ }^{78}$ The major foreign oil producers would have posed the strongest threat to the distribution cartel, for they could have by-passed the refining restrictions and entered the Japanese market with goods produced abroad. To do so, however, they would have had to create new distribution networks. The Shell and Getty subsidiaries joined the

FTC has not issued a final decision. Cf. Tanabe, The Processes of Litigation: An Experiment with the Adversary System, in LAw IN JAPAN, supra note 11, at 73, 85-96 (discussion of power of a Japanese judge to remedy errors made by the parties). See generally Miyamoto, supra note 67, at 79 n.4 (criticizing cases discussed above); Case Comment, 53 Bessatsu juRIsuto 231, 232 (1977) (same).

70. See Antimonopoly Act, supra note $34, \S 25$.

71. See id. $\S 26$.

72. 1005 Hanrei jihō 32 (Tokyo High Ct., July 17, 1981).

73. 997 Hanrei jihō 18 (Yamagata Dist. Ct., Mar. 31, 1981).

74. 863 Hanrei jihō 20 (Tokyo High Ct., Sept. 19, 1977).

75. See Kai v. Nippon Sekiyu, K.K., 1005 Hanrei jihō at 61.

76. See Tsurumi, supra note 27, at 113, 120. But see Idemitsu Kósan, 1108 Hanrei jihō, at 12 (Exxon and Mobil subsidiaries feared Japanese FTC).

77. See Kai, 1005 Hanrei jihō at 61; Tsurumi, supra note 27, at 120 .

78. See Japan v. Sekiyu Renmei, 983 Hanrei jihō 22 (Tokyo High Ct., Sept. 26, 1980).

79. MITI's involvement was apparently part of an ongoing and widespread program of "administrative guidance" in the oil industry. Administrative guidance has been widely discussed in the English-language press, and need not be explained here. See, e.g., C. Jounson, supra note 33, at 265-72 (administrative guidance and MITI); Young, Judicial Review of Administrative Guidance: Governmentally Encouraged Consensual Dispute Resolution in Japan, 84 Colum. L. REv. 923, 923 nn.1-2 (1984) (collecting sources of discussion). A major issue in the oil cartel cases was whether MITI's administrative guidance excused the oil firms and trade association of civil and criminal liability. See Ramseyer, Japanese Antitrust Enforcement After the Oil Embargo, 31 AM. J. CoMP. L. $395,400-08,419-20$ (1983). 
cartel, $^{80}$ and the Mobil and Exxon subsidiaries followed its lead. ${ }^{81}$ Whatever foreign threat might have existed thus failed to materialize. ${ }^{82}$

Nevertheless, for price-fixers the early 1970's were not the best of times. After the outbreak of the Arab-Israeli war, the Arab oil producers slashed their sales to Japan. This economic threat terrified the Japanese public, and the price increases that followed made the public acutely interested in why the market functioned as it did. Taxi drivers struck over a shortage of liquified petroleum gas; housewives rioted over a kerosene shortage. ${ }^{83}$ The FTC had always had a stronger interest than the rest of the Japanese bureaucracy in enforcing the Antimonopoly Act, and saw this period of public discontent as a chance to assert its authority. Under aggressive new leadership, ${ }^{84}$ it raided the offices of the oil companies. ${ }^{85}$ The Commission then began the first Japanese criminal prosecutions for cartelization, charging the petroleum firms and trade association with Antimonopoly Act violations in what would become the most notorious antitrust investigation in Japanese history. The public cheered. ${ }^{\mathbf{8 6}}$

In 1980 , the trial court in these criminal cases held that the oil cartel had been illegal despite MITI's acquiescence. ${ }^{\mathbf{8 7}}$ It acquitted the trade as-

80. The Shell subsidiary, Sheru Sekiyu, K.K., and the Getty subsidiary, Mitsubishi Sekiyu, K.K., see Japan Petroleum \& Energy Yearbook-1978, at G-5 (Japan Petroleum Consultants, Ltd. ed. 1978) (shareholding arrangements), were members of the cartel.

81. See supra p. 618.

82. Of course, the threat of competition from abroad may have prevented the cartel from raising prices above market levels. The $\mathrm{Kai}$ court held that the cartel prices were below market levels, but because of government intervention rather than the threat of competition. See Kai, 1005 Hanrei jiho, at 77. If the court was correct, no foreign firm would have had an incentive to enter the market.

This Article does not attempt to evaluate the empirical economic evidence on pricing in the Japanese oil industry.

83. See C. Johnson, supra note 33, at 298. Many taxis in Japan use liquified petroleum gas rather than gasoline.

84. Toshihide Takahashi became Commissioner in 1972, see SANjūNENSHI, supra note 62, at v, and undertook to enforce the Antimonopoly Act far more stringently than his predecessors. See C. Johnson, supra note 33, at 298-99.

85. See C. Johnson, supra note 33, at 299; Smith, Prices and Petroleum in Japan: 1973-1974-A Study of Administrative Guidance, 10 L. JAPAN 81, 98 (1977).

86. See Tsurumi, supra note 27 , at 122-23. Indeed, the members of a major consumer group, the "Housewives' Federation," repeatedly shouted "banzai" on hearing of the indictments. See C. JoHNson, supra note 33 , at 300 .

87. Japan v. Idemitsu Kōsan, K.K., 985 Hanrei jihō 3 (Tokyo High Ct., Sept. 26, 1980), translated in Ramseyer, supra note 65, at 66, 70-72, aff'd in part and rev'd in part, 1108 Hanrei jiho 3 (Japan Sup. Ct., Feb. 24, 1984); Japan v. Sekiyu Renmei, 983 Hanrei jiho 22 (Tokyo High Ct., Sept. 26, 1980), translated in Ramseyer, supra note 65, at 57, 60-63, 65-66.

The English-language material on these criminal cases includes Haley, The Oil Cartel Cases: The End of An Era, 15 L. JaPan 1 (1982); Matsushita, Problems and Analysis of the Oil Cartel Case Decisions (J. Sameth trans.), 15 L. JAPAN 79 (1982); Ramseyer, supra note 79; Ramseyer, supra note 65; Repeta, The Limits of Administrative Authority in Japan: The Oil Cartel Criminal Cases and the Reaction of MITI and the FTC, 15 L. JAPAN 24 (1982); Sanekata, Administrative Guidance and the Antimonopoly Law-Another View of the Oil Cartel Criminal Decisions, 15 L. JAPAN 95 (1982); Smith, supra note 85; Note, supra note 33. Japanese-language materials on these criminal cases are cited in Appendix to Symposium: The Oil Cartel Cases, 15 L. JAPAN 99-101 (1982).

The antitrust litigation in the oil industry involved four separate sets of suits, each of which is 
sociation and its officials on the grounds that, because of MITI's role, the officials had not been conscious of the illegality of their actions. Nevertheless, it convicted most of the oil companies and their executives. Because the executives had first fixed prices on their own initiative and only later sought MITI's imprimatur, the court believed the executives knew they were violating the law. They appealed, but to no avail. In 1984, the Japanese Supreme Court affirmed the convictions of all but three of the defendants. ${ }^{88}$

The judgment in Kai was rendered soon after these criminal case decisions. The Kai plaintiffs had sued six of the distributors ${ }^{89}$ for price-fixing under the private damage provisions of the Antimonopoly Act. ${ }^{90}$ Proving the antitrust violation was not hard. Although Japanese law lacks any provision making a judgment in a prior government antitrust suit prima facie evidence of a violation, ${ }^{91}$ it also lacks juries. ${ }^{92}$ Not only did the judges in Kai know what the trial court had held in the criminal cases, but $K a i$ and the criminal cases were all tried in the Tokyo High Court. ${ }^{93}$ As one might expect in the wake of the criminal decisions, the court in $K a i$ found that the defendants had fixed prices and violated the Antimonopoly Act. ${ }^{94}$

summarized in Ramseyer, supra note 65, at 73-78.

88. Japan v. Idemitsu Kōsan, K.K., 1108 Hanrei jihō 3 (Japan Sup. Ct., Feb. 24, 1984). For commentaries on this decision, see Hatakeyama, Sekiyu karuteru hanketsu to gyosei shido [The Oil Cartel Decision and Administrative Guidance], 813 JuRIsuro 6 (1984); Hayashi, Sekiju karuteru no keiji sekinin [The Criminal Responsibility of the Oil Cartel], 813 JuRIsuTo 10 (1984); Kitani, Sekiyu karuteru (kakaku kyōtei) jikkin jökokushin hanketsu ni tsuite [Regarding the Appellate Decision in the Oil Cartel Price-fixing Case], 813 JuRIsuto 17 (1984). For commentary on the decision in an official government journal, see Hayashi, Gyōsei shito ni yoru jigoösha no karuteru koi to Dokusen kinshi hō no kankei ni tsuite no Saiǩosai no shinhanrei [Recent Supreme Court Decision Regarding Relation Between Antimonopoly Act and Cartelization by Business Pursuant to Administrative Guidance], 1223 TOKI NO HŌREI 54, 1224 TOKI NO HŌREI 53, 1225 TOKI NO HÖREI 52 (1984).

89. The plaintiffs sued under Antimonopoly Act $\S 25$, which allows suits only after a final FTC administrative decision. Six of the twelve members of the cartel had contested in court the FTC action against the cartel. See Idemitsu Kōsan, K.K. v. Kōsei Torihiki İnkai, 32 Sai-han minshū 533 (Tokyo High Ct., Sept. 29, 1975), aff d, 32 Sai-han minshū 515 (Japan Sup. Ct., Apr. 4, 1978); Ramseyer, supra note 65 , at 74 . To avoid the argument that the FTC action against those six was not final, the plaintiffs sued only the six who did not contest the FTC decision. See Miyamoto, supra note 67, at 81.

90. Antimonopoly Act, supra note 34, § 25.

91. Compare Antimonopoly Act, supra note 34 (no provision giving weight to prior judgment in suit brought by government), with Clayton Act § 5(a), 15 U.S.C. § 16(a) (1982) (final judgment in suit brought by government is prima facie evidence against defendants in subsequent private action). See also Tanaka \& Takeuchi, supra note 28 , at 44 (judgment against defendant in government suit is not evidence of violation in subsequent suit by private citizen). But see Miyamoto, supra note 67, at 82-83 (prior judgment may have considerable probative value despite absence of collateral estoppel).

92. For a historical discussion of the Japanese use of the jury system, see the materials collected in The JaPanese Legal System, supra note 11 , at $482-91$.

93. The Tokyo High Court, although generally an appellate court, has original jurisdiction over both antitrust criminal cases and damage suits brought under $\S 25$ of the Antimonopoly Act. See Antimonopoly Act, supra note $34, \S 85$. Kai involved a different panel of judges than the criminal cases.

94. See Kai, 1005 Hanrei jihō at 71-72. 
The plaintiffs in Kai lost, however, for failure to prove their damages. The court's holding results from two analytic decisions it made: First, accepting the defendants' price discrimination scheme as effective, it ignored price increases in the kerosene allegedly sold exclusively to industrial users, and second, it calculated the plaintiffs' damages as only the difference between the cartel price and a hypothetical market price-even though it believed that the distributors had been selling kerosene at a below-market price prior to the cartel.

\section{Price Discrimination}

At the time of the cartel, the distributors had separately marketed two products, consumer-use kerosene and industrial-use kerosene. The two products were, however, identical. The different labels merely reflected the distributors' response to pressure from MITI to price-discriminate and charge higher prices to large-scale industrial users..$^{95}$

The distributors apparently restricted the availability of the lowerpriced consumer-use kerosene and sold the remainder as the higher-priced industrial-use product. ${ }^{96}$ Yet the opinion gives no indication that the distribution channels for the two products were such that the distributors could have raised prices to industrial users without affecting consumer prices. Indeed, the plaintiffs testified that some retailers told them they could have kerosene only if they purchased it at industrial-use prices. ${ }^{97}$ Nevertheless, the court apparently believed that the sellers were generally able to keep the two distribution channels distinct. ${ }^{98}$ The court further asserted that even if the higher industrial-use prices did in fact induce some dealers to repackage consumer-use kerosene as industrial-use, such actions were not the result of the cartel.90

Because it determined that the increases in the price of industrial-use kerosene did not result in higher prices to the plaintiffs, the court held that the plaintiffs could have been affected by only two of the five price agreements in 1973, those increasing the price of consumer-use ker-

95. See id. at 65; Miyamoto, supra note 67, at 87; Shōda, Tōyu saiban no hanketsu o meguru mondaiten: ka [Issues in the Kerosene Trial Decision: Part II], 776 JuRIsuTo 115, 115 (1982).

96. The distributors sold only $70 \%$ to $80 \%$ of the kerosene as consumer-use kerosene. See Kai, 1005 Hanrei jihō at 73-74.

As a form of price discrimination, this arrangement was a crude scheme. Price discrimination is difficult to enforce. In general, a seller can successfully charge different prices to two groups of users only if one group in fact values the product more highly than the other, the seller can prevent buyers who value the product more highly from purchasing the product at the lower price, and the seller can estimate accurately the quantity demanded by each group. See S. Breyer, Regulation and ITS REFORM 17-18 (1982).

97. See Kai, 1005 Hanrei jihō at 74.

98. See id. at 65. But see Miyamoto, supra note 67, at 87 (arguing that channels were not distinct); Shōda, supra note 95, at 115 (same).

99. See Kai, 1005 Hanrei jihō at 74. 
osene. ${ }^{100}$ Those two agreements together increased kerosene prices by a mere 1.5 cents per gallon. ${ }^{101}$ By ignoring the increases in the price of industrial-use kerosene, the court effectively insured that the plaintiffs would recover at most an insignificant amount.

\section{Damage Formula}

By misapplying the standard damage formula, the court destroyed any remaining chance of recovery. The court held the plaintiffs entitled to the difference between the market price of kerosene and the cartel price. ${ }^{102}$ Under competitive circumstances, that formula would of course yield the correct result. The oil industry, however, had been under MITI's supervision for several years, and the court believed that MITI had kept kerosene prices below market levels. ${ }^{103}$ The court noted that although freight and crude oil costs had risen, the demand for kerosene had increased. ${ }^{104}$ As a result, the court believed that kerosene prices had remained below the hypothetical market prices even after the defendants' price-fixing efforts. ${ }^{105}$ Although kerosene prices were higher during the cartel than they had been before, they remained lower than they would have been had prices been determined by market forces. As a result, the court held, the plaintiffs had suffered no injury.

The court did not arrive at this somewhat peculiar conclusion for lack of an alternative. The FTC, for example, had urged the court to measure the plaintiffs' damages as the difference between the cartel price and the pre-cartel price. ${ }^{106}$ Although that difference would not represent a cartel's overcharge in a market economy in flux, it might well represent that overcharge in a market subject, as the court believed to be the case in $K a i$, to government price controls. After all, if the pre-cartel kerosene price were indeed a controlled price, then it would have approximated kerosene prices in the absence of the cartel. The difference between that price and

100. The court held that the defendants had fixed prices on five occasions in 1973-January, February, August, October, and December-but that the price of consumer-use kerosene was involved only in the price increases of August and October. See id. at 61-67.

101. The August increase was 1,000 yen per kiloliter, or approximately 1.5 cents per gallon, $i d$. at 74-75. The court believed that the October increase was merely an effort to enforce the August increases without raising prices further. See id. at 66, 74-75.

102. See id. at 75 .

103. See id. (beginning April, 1971, MITI engaged in administrative guidance to restrain increases in price of kerosene).

104. See id. at 76-77; Shōda, supra note 95, at 116.

105. See Kai, 1005 Hanrei jihō at 77.

106. See id. at 81-88 (FTC opinion on damages); Kikuchi, Dokusen kinshi ho ihan koisha no minji sekinin: ka [The Civil Liability of Antimnnopoly Act Violators: Part 11], 270 NBL 32, 38; Cf. Shōda, Kakaku karuteru ni yoru higai to songai baisho [Damage Compensation and the Damages Caused by a Cartel], 699 JuRIsuTo 101, 104-05 (1979) (suggesting similar measure of damages). 
the cartel price would then have represented the plaintiffs' damages. ${ }^{\mathbf{1 0 7}}$ This approach, however, was one the court rejected.

\section{Satô v. Sekiyu Renmei}

The claims of the Sato plaintiffs arose from the same activities in the oil industry as the claims in $\mathrm{Kai}$ and had two parts: price-fixing allegations against the distributors and production-limitation allegations against the trade association. Unlike the Kai plaintiffs, however, the plaintiffs in Sato did not sue under the Antimonopoly Act. Instead, they argued that an antitrust violation was an intentional tort and sued the kerosene distributors under the general tort damage provisions of the Civil Code. ${ }^{108}$ The Japanese Supreme Court had suggested such a theory in $1972,{ }^{108}$ but this was the first case in which a plaintiff had relied on the argument. The plaintiffs had three reasons to sue under a tort theory: They could sue those firms against whom the FTG had not issued a final administrative decision; they could sue the petroleum trade association as well as the distributors; and they could sue in local court. Under the Antimonopoly Act, they could have sued only those firms subject to final administrative actions, ${ }^{110}$ only private firms, ${ }^{111}$ and only in Tokyo High Court. ${ }^{112}$ Under the Antimonopoly Act, however, the plaintiffs would have had a strict liability cause of action. ${ }^{113}$ Because they sued under general tort princi-

107. Instead, the court's formula effectively eliminates private damage actions in those sectors of the economy where the government has maintained below-market prices. Perhaps the only way to justify the court's approach is to recognize MITI's efforts to control prices as illegal-as the Tokyo High Court seemed to suggest in the criminal case. See Sekiyu Renmei, 983 Hanrei jihō at 58-59. If MITl's instructions were illegal, then the pre-cartel price resulted from illegal activities. If the defendants colluded to raise that price to market levels, they merely eliminated the consequences of those illegal actions. The Kai court eliminated this justification for its formula, however, by suggesting that MITI's price activities were legal. See 1005 Hanrei jihō at 72; see also Idemitsu Kósan, 1108 Hanrei jihō at 13-14 (MITI's activities declared legal).

108. MiNPō $\S 709$ : "A person who violates intentionally or negligently the right of another is bound to make compensation for damages arising therefrom."

109. See Ebisu Shokuhin Kigyō Kumiai v. Kōsei Torihiki Iinkai, 26 Sai-han minshū 1573, 1576 (Japan Sup. Ct., Nov. 16, 1972); Tanihara, Case Comment, 1013 Hanrei jiho 170, 171-72 (1981).

110. See Antimonopoly Act, supra note $34, \S 26$. Apparently because of such considerations, the Kai plaintiffs sued only six of the twelve cartel members. Japanese tort law, however, has traditionally provided for joint and several liability. Minpō $\$ \S 432,719$; K. TAKanashi, Minpō [GiviL CODE] 190, 192, 276 (1965). If the Antimonopoly Act were governed by the same principle, the Kai plaintiffs could have recovered their entire damages from the six defendants. The Antimonopoly Act does not discuss joint and several liability and no case to date has addressed the issue. Note that the tort law regarding joint and several liability is currently in flux. See $3 \mathrm{~K}$. IgARASH, H. END̄̄, T. Kawai \& I. Shimazu, Minpō gaku no kiso chishiki [Basic Knowledge of Civil Code StudIES] § 9-82 (1975); Kanchiku, Kyōdo fuhō kōi no seiritsu han'i [The Prerequisites for Joint Liability], 515 Hanrei taimuzu 65, 65 (1984); Case Comment, Höritsu jirō, Jan. 1983, at 59.

111. Section 25 of the Antimonopoly Act, supra note 34, does not authorize suits against trade associations. See Shōda, supra note 106, at 105 (discussing lack of Antimonopoly Act cause of action against trade associations).

112. See Antimonopoly Act, supra note $34, \S 85$.

113. See id. § 25. 
ples, the Sato plaintiffs needed to prove either negligence or intentionality. ${ }^{114}$

The plaintiffs in Sato had little trouble proving that the defendants had acted illegally and intentionally. ${ }^{115}$ By the time the Sato court decided the case, the Tokyo High Court had already convicted the petroleum firms of price-fixing ${ }^{116}$ and the Sato court borrowed the High Court's analysis of illegality. ${ }^{117}$ Moreover, because the plaintiffs proved that the defendants had realized their acts would produce the consequences of which the plaintiffs complained, the court held that the plaintiffs had proven intent. ${ }^{118}$ A lack of consciousness of illegality may preclude a finding of criminal intent, ${ }^{119}$ but it was no defense in Sato to a tort action. ${ }^{120}$

\section{Price-fixing}

The price-fixing aspect of the Sato decision was every bit as senseless as that in Kai. Like the Kai court, the Sato court ignored the price increases in industrial-use kerosene ${ }^{\mathbf{1 2 1}}$ and concluded that only two of the price increases in 1973 could have damaged the plaintiffs. ${ }^{122}$ Ultimately, however, the plaintiffs in Sato lost their price-fixing claim because the court believed they failed to show the causal link between the defendants' pricefixing activities and their damages.

The causation issue in Sato was essentially a "pass on" problem. The Sato court noted that, before reaching the consumer, the kerosene sold by the distributors sometimes passed through as many as four separate sell-

114. Minpō $\$ 709$.

115. Sato, 997 Hanrei jihō, at 83-84.

Note that some scholars in Japan have argued that price-fixing is a question of negligence rather than intent. See Okujima, Tsuruoka toyu hanketsu no mondaisei [The Problematic Character of the Tsuruoka Kerosene Decision], 443 HaNREI TAIMuzu 6, 7-8 (1981); Shōa, Antimonopoly Law Violation and Compensatory Damages, 16 L. JAPAN 1, 8 (1983); Shōda, Dokkinho to no shinketsu to songai baisho [Damage Compensation and [Administrative] Decisions Based on the Antimonopoly Act ], 607 Jurisuto 117, 119 (1976). See Case Comment, 53 Bessatsu Jurisuto 231, 232 (1977) (following Shōda).

116. See Idemitsu Kosan, 985 Hanrei jiho at 17-44. The court also held that the Petroleum Federation had violated the law, but acquitted it on the grounds that its officials had not been conscious of the illegality of their actions. See Sekiyu Renmei, 983 Hanrei jihō at 57-66.

117. The discussion of illegality in Sato, 997 Hanrei Jiho at 75, is apparently based on the analysis of the issue in Sekiyu Renmei, 983 Hanrei Jiho at 58-59, though the Sato court makes several errors not found in Sekiyu Renmei. See Ramseyer, supra note 79, at $420 \mathrm{nn} .175$ \& 176. 173.

118. See Sato, 997 Hanrei jihō at 84; Negishi, supra note 67, at 98; Tanihara, supra note 109, at

119. See Sekiyu Renmei, 983 Hanrei jiho at 60-66. For a fuller discussion of the relation between criminal intent and consciousness of illegality, see Ramseyer, supra note 79, at $400 \mathrm{n} .33,404-05$.

120. See Sato, 997 Hanrei jihō at 84; Negishi, supra note 67, at 98.

121. See Sato, 997 Hanrei jihō at $76-80,87$.

122. It found that plaintiffs were damaged only by the August and October increases. See id. at 78-79. Moreover, like the Kai court, the Sato court believed that the October price increase was merely a consolidation of the August increase. See Sato, 997 Hanrei jihō at 82. 
ers, each of whom might absorb a portion of a price increase. ${ }^{123}$ The court did find that the defendants had successfully fixed their prices. ${ }^{124}$ It even held that these increases had led to higher prices being charged to the plaintiffs' sellers. ${ }^{125}$ It denied the plaintiffs' claims, however, on the ground that the plaintiffs' sellers had not raised the prices they charged. The plaintiffs had, in other words, successfully proven that the cartel's price increases had travelled the entire distribution chain-except the last link.

The analysis by which the court concluded that the plaintiffs' sellers had not raised their prices is a peculiar one indeed. The plaintiffs had bought most of their kerosene from a cooperative, but failed to name it as a party plaintiff. The court treated this cooperative as a third-party seller rather than as the plaintiffs' purchasing agent. This distinction was crucial. It meant that the plaintiffs would have to prove that the cooperative had raised the prices it charged its members. ${ }^{126}$ As a service to those members, however, the cooperative had consistently sold kerosene at belowmarket prices and did not significantly increase its kerosene prices in late 1973 or early $1974 .{ }^{127}$ Instead, because it charged low prices, it found itself with a kerosene shortage. ${ }^{128}$ These facts suggest that the plaintiffs suffered two forms of injury: First, the kerosene shortage at the cooperative forced them to buy kerosene from other sellers at higher, cartel-caused prices, and second, as members and therefore presumably owners of the cooperative they lost profits because the cooperative absorbed the cartel's higher prices. The court rejected the first possible injury on grounds of inadequate proof:; $;{ }^{129}$ the second it did not even discuss.

\section{Production Restrictions}

The court also rejected the plaintiffs' claim that the trade association had raised consumer prices by restricting kerosene production. Again, the problem involved the extent of the "pass on." The court pointed to other factors-such as the increased industrial demand for kerosene, the abnormally cold winter, increased delivery costs, and various transportation difficulties-all of which might have contributed to the higher prices. There simply was insufficient proof, it held, that the association's restrictions,

123. See Sato, 997 Hanrei jihō at 85-86.

124. See id. at 87 .

125. See id. at 88 .

126. See id.

127. See id. at 89,90 .

128. See id. at 89.

129. See $i d$. 
rather than these factors, had caused whatever kerosene price increases there might have been. ${ }^{130}$

\section{Okawa v. Matsushita Denki Sangyō, K.K.}

The only other antitrust damage action decided on the merits was a resale price maintenance suit by consumers against a television manufacturer: Okawa v. Matsushita Denki Sangyo, K.K. ${ }^{131}$ Although resale price maintenance analytically bears little relation to cartelization, the court's disposition of Matsushita Denki closely resembles the opinions in Kai and Sato. The plaintiffs in Matsushita Denki argued that the manufacturer had sold its products only to wholesalers who dealt exclusively in Matsushita Denki products, had instructed those wholesalers to boycott retailers who sold Matsushita Denki products at heavily discounted prices, and had instructed the wholesalers to sell its products to retailers only at specified prices. ${ }^{132}$

Despite its belief that Matsushita Denki had indeed engaged in resale price maintenance and raised consumer prices, the court rejected the plaintiffs' claims on the ground that they had failed to prove the extent of their damages. ${ }^{13 s}$ The court defined the plaintiffs' damages as the differ-

130. See id. at $86-87,89-90$.

131. 863 Hanrei jihō 20 (Tokyo High Ct., Sept. 19, 1977). Matsushita Denki produces electrical appliances sold under such names as National, Panasonic, Quasar, and Technics.

132. Id. at 21-22; see Negishi, Case Comment, 900 Hanrei jihō 143, 143 (1978).

Where retailers pressure a manufacturer to introduce a resale price maintenance scheme, the arrangement may represent an attempt by retailers to enforce a horizontal price-fixing agreement. E. Gellhorn, Antitrust Law and Economics in a Nutshell 257 (2d ed. 1981). The Matsushita Denki plaintiffs alleged nothing of the sort, however, and true resale price maintenance is virtually self-policing since it runs counter to a manufacturer's basic interests. See Posner, The Next Step in the Antitrust Treatment of Restricted Distribution: Per Se Legality, 48 U. CHI. L. REv. 6, 22-23 (1981) But see Kaplow, The Patent-Antitrust Intersection: A Reappraisal, 97 HaRv. L. REv. 1813, 1862-63 \& n.171 (1984) (resale price maintenance might produce monopoly gain). If retailers reduce their prices, they will sell more products-and if a manufacturer has not cut his wholesale price, he will simply make a proportionately larger profit. Resale price maintenance thus serves a manufacturer's interests only if the minimum price induces retailers to compete on non-price terms like advertising and service and thereby increase the total sales of the manufacturer's goods.

In the absence of dealer pressure to maintain prices, Matsushita Denki's efforts probably represented such an effort to encourage its dealers to promote and service its products. Nevertheless, resale price maintenance agreements appear generally to be illegal in Japan, except as so designated by the FTC. See Antimonopoly Act, supra note $34, \S \S 2(1), 19,24-2,25$. As such, they represent conduct for which a consumer may sue for damages under the Antimonopoly Act. See generally 2 A. SHŌDA, DOKUSEN KINSHI HŌ KENKYU] [STUDIES IN THE ANTIMONOPOLY ACT] 187-97 (1976); Covey, Vertical Restraints Under Japanese Law: The Antimonopoly Law Study Group Report, 14 L. JAPAN 49, 62 (1981); Haley, Marketing and Antitrust in Japan, 2 Hastings INT'L \& CoMP. L. Rev. 51, 62-65 (1979); Negishi, Saihanbai kakaku iji [Resale Price Maintenance], in DokusEn KINSHI нō o MANABU [LEARning THE ANTIMonopoly ACT] 168-76 (A. Shōda \& K. Sanekata eds. 1976); Tsuji, Regulation of Resale Price-Maintenance in Japan, 18 N.Y.L.F. 397 (1972).

133. Matsushita Denki, 863 Hanrei jiho at 28-30. But see Negishi, supra note 132, at 148-49 (arguing that it is unclear whether the Matsushita Denki court failed to find damages or failed to find causation). 
ence between the actual retail price and the market price, ${ }^{134}$ and held that the plaintiffs had failed to prove the latter. Yet the plaintiffs could hardly have proffered much more proof than they did. The market price is by definition a fictitious price. In order to suggest what that price would have been in the absence of a price maintenance scheme, the plaintiffs proved the price for Matsushita Denki television receivers among wholesalers not exclusively dealing in Matsushita Denki products and the price of the receivers at various discount outlets. ${ }^{\mathbf{1 3 5}}$

The court was not satisfied. It noted that the price among the nonMatsushita Denki wholesalers was apparently a composite price of products that included receivers sold by cash-short and bankrupt retailers. ${ }^{136}$ It considered the prices charged by the discount houses to be a poor index, since the discount houses bought their sets on this wholesale market and operated at a smaller retail markup than could the local stores from which the plaintiffs had purchased their receivers. ${ }^{137}$ Given the hypothetical character of the "market" price for the receivers, however, there was little other evidence the plaintiffs could have offered. ${ }^{138}$

\section{Antitrust Damage SuIts: The BarRIERS}

This, then, is the extent of antitrust damage litigation in Japan: two cases settled out of court, two cases dismissed for lack of a final FTC disposition, and Kai, Sato, and Matsushita Denki. Of course, some pricefixers may have "bought off" potential plaintiffs before suit. ${ }^{139}$ If such settlements were common, they would themselves deter price-fixing. Nevertheless, seven is a small number of claims even if one allows for unrecorded settlements. ${ }^{140}$ And to the extent that litigation is an unrealistic option, a cartel's victims will settle for smaller amounts than they would otherwise. ${ }^{141}$ Considered in the context of the institutional barriers to Japanese litigation-some particular to antitrust suits, others applicable to all lawsuits- this paucity of lawsuits becomes less surprising. ${ }^{142}$

134. Matsushita Denki, 863 Hanrei jihō at 29.

135. See id. at 30 .

136. Id.

137. Id.

138. Negishi, supra note 132 , at $149-50$, suggests that the plaintiffs might also have proven the price at which the manufacturer sold the receivers to its buyers and then added an appropriate profit margin to that price, but that they were unable to obtain even this information. See infra pp. 631-32 (importance of discovery).

139. Because Kai, Sato, and Matsushita Denki involved large numbers of indirect purchasers, they probably could not have been settled before they were filed. There is no reason, however, that direct purchasers could not settle before they file suit.

140. By contrast, over 9000 private antitrust cases were filed in the United States from 1945 to 1969. See Posner, supra note 65, at 371.

141. See, e.g., R. Posner, supra note 8 , at 435.

142. Some of these barriers have even become the object of attention in the American popular 


\section{A. Barriers to Antitrust Litigation}

Several of the barriers illustrated by these cases are specific to antitrust litigation. Consider, for example, the "pass-on" defense. ${ }^{143}$ Sato involved indirect purchasers, and the crucial issue in the case became the classic pass-on problem: whether when a product passed through a complicated distribution channel over several months at a time when the economy as a whole was undergoing rapid changes, the actions of the ultimate seller resulted in the price increases to the ultimate buyer. Although also indirect purchasers, the plaintiffs in Kai did not lose directly over a pass-on issue. Yet despite the $\mathrm{Kai}$ court's misplaced concern over market prices, some evidence suggests that its economic analysis was wrong and that cartel prices may in fact have been above market levels. ${ }^{144}$ If so, the plaintiffs' inability to prove the true market price may in part have been a function of their inability as indirect purchasers to prove the effect of intervening factors like freight costs and crude oil prices. To that extent, $\mathrm{Kai}$ becomes a pass-on case as well. ${ }^{145}$

As one solution to the "pass on" problem, American courts have al-

press. See, e.g., Mayer, Japan: Behind the Myth of Japanese Justice, AM. LAw., July-Aug. 1984, at 113.

Other deterrents exist as well, of course. Plaintiffs in Japan must pay a "stamp tax" at the time they file suit, calculated as a percentage of the damages they assert. The percentage varies from approximately $0.16 \%$ to $0.8 \%$. See Minji soshō hiyō tō ni kansuru hōritsu [Law Concerning Civil Litigation Costs, Etc.], Law No. 40 of 1971, $\S \$ 4,8$, Tab. 1. An additional tax is payable upon appeal.

The absence of offensive collateral estoppel may deter some litigation by preventing plaintiffs from making use of prior judgments. On the absence of collateral estoppel in Japan, see Kikuchi, Kōsei Torihiki Iinkai kakutei shinketsu no horjoku: Minji sosȟo to no kosaku wo chushin ni [The Binding Power of FTC Decisions-Their Relation to Civil Litigation], 24 AOYAMA HOGAKU RONSHU 117, 124-37; Mikazuki, supra note 91, at 38; Tanaka \& Takeuchi, supra note 28 , at 44. But see Miyamoto, supra note 67 , at $82-83$ (prior judgment may have considerable probative value despite absence of collateral estoppel).

The statutory authorization of cartels is arguably one of the most effective institutional barriers to antitrust damage suits. Since 1953, the Antimonopoly Act has permitted firms in industries meeting various requirements to fix prices by forming "depression cartels," see Antimonopoly Act, supra note $34, \S 24-3$, and many firms have formed cartels by obtaining other statutes specifically exempting their industry from the provisions of the Antimonopoly Act. Cf. E. HADLEY, supra note 31, at 373-81 (few cartels formed under Antimonopoly Act itself); K. YamamuRa, supra note 35, at 54-86 (increase in number of cartels). See generally Note, supra note 33, at 1070-71 (rationalization and depression cartels exempted from Antimonopoly Act).

143. It has apparently been clear only since Matsushita Denki that indirect purchasers could sue - and that "passed on" costs would therefore probably be a defense. See Atsuya, Tökjō Kōsai töju songai baishō seikȳu sosho ni tsuite [On the Tokjo High Court Kerosene Private Damage Litigation], 458 Hanrei Taimuzu 2, 3 (1982); Negishi, supra note 132, at 146. Thus, the "pass on" issue does not itself explain why so few parties sued prior to 1977. But see id. at 146 (ability of consumers to sue was established scholarly position prior to Matsushita Denki).

144. Tsurumi, supra note 27, at 119-21 (oil firms conspired in early 1971 to fix prices in order to overcome MITI's "policy of forcing the oil industry into price competition"); see J. WHEELER, M. Janow \& T. Pepper, Japanese Industrial. Development Policies in the 1980s, at 172 n.2 (1982); Shōda, supra note 95, at 117-18.

145. See Shōda, supra note 95, at 117-18 (noting pass-on problem in Kai). 
lowed only direct purchasers to sue, but denied the defendant the defense that the direct purchasers have "passed on" some of the price increase to others. ${ }^{148}$ The American rule grants the cause of action to the parties with the easiest access to the information necessary to maintain the suit and permits those parties to collect not only their own damages but also the damages suffered by those to whom they in turn sold the goods. Japanese courts allow a larger number of plaintiffs to sue, but each plaintiff may sue only for a smaller amount of damages and only after incurring the larger litigation costs necessary to disprove the defendant's pass-on defense. Thus, although none of the plaintiffs in Kai and Sato could have sued under the American rule, the American rule increases the chance that someone will successfully sue a price-fixer, and in so doing increases the deterrent value of private damage litigation.

Had Japanese courts wanted to allow indirect purchasers to recover their damages, they could have taken several other approaches. The courts could, for example, have allowed both direct and indirect purchasers to recover the entire amount of the defendants' price increases. Had the courts been worried about the potential double recovery such a scheme would allow, they could have adopted a rebuttable presumption: ${ }^{\mathbf{1 4 7}}$ Once the plaintiffs had proven a price-fixing agreement, the courts could have presumed that the price-fixers had caused any subsequent price increases up to the amount by which the defendants initially raised their prices. ${ }^{148}$

Even though the court rejected the use of presumptions, it could have given more weight than it did to the FTG's opinion on damages. The Antimonopoly Act explicitly requires that, whenever a plaintiff brings a private damage action under the Act, the court must obtain from the FTG an opinion on damages. ${ }^{148}$ This requirement suggests that the drafters intended the courts to give weight to the Commission's estimate, ${ }^{150}$ and the estimate would necessarily have included a discussion of the amounts the seller had "passed on" to the plaintiffs. Nevertheless, the issue did not arise in Matsushita Denki, ${ }^{161}$ and in $K a i$ and Sato the court dismissed the FTC's opinion almost out-of-hand. ${ }^{162}$

146. See supra pp. 614-15.

147. See Kikuchi, supra note 106, at 37 (advocating a presumption); Okujima, supra note 115, at 13 (same).

148. Such a presumption would be sensible if, as seems probable, a producer in Japan is more likely than a consumer to have access to the information necessary to prove the extent to which a retailer passes on a price increase. See Miyamoto, supra note 67, at 86; Negishi, supra note 67, at 99.

149. See Antimonopoly Act, supra note $34, \$ 84$.

150. See Shōda, Dokkinhō, supra note 115 , at 120 .

151. The FTC stated that it was unable to issue an estimate because it had collected insufficient information in the course of its administrative proceedings. See Matsushita Denki, 863 Hanrei jihō at 30.

152. In Kai, the court rejected the FTC's estimate on the grounds that the Commission had based its calculations on the difference between the plaintiff's prices and the pre-cartel prices. See Kai, 1005 
Kai, Sato, and Matsushita Denki also demonstrate that Japanese courts impose an almost impossibly high standard of proof on damages in antitrust cases. ${ }^{153}$ Although slightly different factors contributed to the unrealistically high standard in each case, the difficulty of proof ultimately seems to derive from the courts' unwillingness to engage in economic analysis on issues that involve fundamentally economic questions. The $\mathrm{Kai}$ and Sato courts concluded that by denominating thirty percent of kerosene "industrial-use" and raising its price, a cartel would not affect the price of the remaining seventy percent, even if industrial users purchased the consumer-use product-yet elementary supply and demand analysis suggests the contrary. ${ }^{154}$ The Kai and Matsushita Denki courts refused to consider any estimates of damages and insisted that the plaintiffs prove the nonexistent market price as though it were an entry in a bookkeeping ledger. ${ }^{155}$ In fact, however, such a hypothetical price depends on supply and demand elasticities and the plaintiffs could prove nothing but estimates. ${ }^{156}$

Hanrei jihō at 78. There was simply inadequate proof, it explained, that the pre-cartel price would have been the market price in the absence of the price-fixing agreement. Id. In Sato-which was not brought under the Antimonopoly Act-the court declared that the FTC had simply ignored the problem of causation and had assumed that the price-fixing arrangement had raised retail prices. See Sato, 997 Hanrei jihō at 85.

153. In fact, Japanese courts have insisted upon a more demanding standard of proof for damages than American courts in most areas of law. See Tsubota, Myth and Truth on Non-Litigiousness in Japan, U. CHI. L. SCH. REc., Spring 1984, at 8, 10. The problem of proof becomes especially acute, however, when it involves the determination of a hypothetical market price.

In Japan, the primary debate over proof of damages has involved the probative value of consent decrees and cease-and-desist orders. Several prominent scholars have argued that various types of FTC orders should bind subsequent judicial actions. For a summary of the debate, see Kikuchi, supra note 142; Ramseyer, supra note 79, at 421 n.181; Symposium, Dokkinhō to minji sekinin [The Antimonopoly Act and Civil Liability], 4 KEIZAI HŌGAKKAI NENPo 83, 89-90 (1983). The courts have consistently rejected the notion that FTC decisions should bind the courts, and rightly so. See Idemitsu Kōsan, K.K. v. Kōsei Torihiki Iinkai, 32 Sai-han minshū 515, 521 (Japan Sup. Ct., Apr. 4, 1978); accord Kai, 1005 Hanrei jihō at 59; Sato 997 Hanrei jihō at 71; Matsushita Denki, 863 Hanrei jihō at 27-28; Nobo Indasutorii, K.K. v. Kōsei Torihiki Iinkai, 800 Hanrei jihō 35, 37 (Japan Sup. Ct., Nov. 28, 1975). Any other result would impose liability on defendants who have had no trial on the factual issues, and could severely hamper the FTC's enforcement efforts by making parties far less likely to accept consent decrees and cease-and-desist orders.

154. This assumes, of course, that the producers were able to control the quantities of the two types of kerosene supplied.

155. See generally, Kikuchi, supra note 106, at 38-39 (difficulty of proving antitrust damages in Japan); Negishi, supra note 132, at 149 (criticizing Matsushita Denki's standard of proof).

156. This demand for precision sharply contrasts with the American rule, under which courts require less proof on the amount of the plaintiff's injury than on the fact that a plaintiff was injured. See P. AREEDA, supra note 41, II 159, at 78; Breit \& Elzinga, Antitrust Enforcement and Economic Efficiency: The Uneasy Case for Treble Damages, 17 J.L. \& ECoN. 329, 343 (1974). As the Supreme Court put it, "there is a clear distinction between the measure of proof necessary to establish the fact that petitioner had sustained some damage, and the measure of proof necessary to enable the jury to fix the amount." Story Parchment Co. v. Paterson Parchment Paper Co., 282 U.S. 555, 562 (1931). "[J]Juries are allowed to act upon probable and inferential, as well as direct and positive proof,", Bigelow v. RKO Radio Pictures, Inc., 327 U.S. 251, 264 (1946) (quoting Story Parchment Co., 282 U.S. at 564), the Court explained, because "[t]he most elementary conceptions of justice and public policy require that the wrongdoer shall bear the risk of the uncertainty which his own wrong has 


\section{B. Barriers to Litigation Generally}

Several of the barriers to litigation that inhibit antitrust suits apply with equal force to other forms of litigation. For example, the Japanese civil procedure code does not permit class actions. ${ }^{167}$ Although it allows representative plaintiffs to litigate common issues, ${ }^{158}$ the decision binds only those plaintiffs who have agreed to be bound. ${ }^{158}$ As a result, many victims of antitrust or other violations are unable to raise the damage pool high enough to make litigation financially worthwhile. The total damages demanded in Sato, for instance, were $\$ 19,000$, in Matsushita Denki $\$ 860$, and in Kai $\$ 370 .^{180}$ In the many sectors of the economy where cartels inflict small amounts of damages on a large number of individuals, class action suits represent the only effective deterrent to anti-competitive conduct. ${ }^{181}$

Japanese discovery provisions represent a further barrier to litigation, for Japanese civil procedure provides few means of effective discovery either before or during trial. In fact, parties often can demand the production of documents only if they can both demonstrate that they have a substantive legal interest in the documents-as, for example, in a contract between the parties-and point to the identities and locations of the documents. ${ }^{102}$ This absence of any significant discovery creates enormous ad-

created." Id. at 265. In price-fixing cases, American courts often use the pre-cartel or post-cartel price, adjusted for any intervening circumstances, to determine what the market price would have been. See P. AREEDA, supra note 41, II 159 (and cases cited therein).

157. See Kikuchi, Dokusen kinshi hö ihan kōisha no minji sekinin: jo [The Civil Liability of Antimonopoly Act Violators: Part I] 265 NBL 28, 30 (discussing implications of lack of class actions for antitrust enforcement); Kimura \& Kuboi, Waga kuni ni okeru sh̄udan sosho no jitsujo to kadai [The State of Group Litigation in Our Nation and the Issues Involved in Such Litigation], 671 JuRISuro 60, 65-67 (1978); Tanaka \& Takeuchi, supra note 28, at 43.

158. See Minji soshō нō § 47.

159. Matsuura, Sentei tojisha [Selected Parties], in MiNJi soshö Procedure LAw] 60-62 (H. Kaneko \& N. Koyama eds. 1970).

160. See Matsushita Denki, 863 Hanrei jihō at 21 (172,300 yen); Case Comment, 1005 Hanrei jihü 32, 33 (1981) (Kai: 75,081 yen); Case Comment, 997 Hanrei jihō 18, 18 (1981) (Sato: 3,895,458 yen). In the third oil cartel private damage action, settled out of court in 1981, the plaintiffs demanded approximately 363,000 yen. See Tōyu saiban nigai wakai, supra note 67 , at 23 .

For a discussion of the non-financial goals of the Sato plaintiffs, see S. UEda, SAIBAN to minshu SHUGi [Litigation AND DemocRaCY] 198-213 (1979); Miyamoto, supra note 67, at 79, 88.

161. See supra note 46.

Even in the United States, however, class actions hardly represent a panacea for private law enforcement. The typical class attorney has a stake only in maximizing his or her fee, while the class members have an interest in maximizing the total damage recovery. Because the class attorney is largely unsupervised, a defendant may be able to exploit this conflict of interest to obtain a smaller total settlement in exchange for a larger attorneys' fee. See Dam, supra note 55, at 56-61; Rosenfield, An Empirical Test of Class-Action Settlement, 5 J. LeGAL STud. 113, 115 (1976). Even a bribe to the plaintiff's attorney, however, is a cost to the defendant and has some deterrent effect.

162. See generally Harada, Civil Discovery Under Japanese Law, 16 L. JAPAN 21 (1983). Japanese courts may, however, be becoming more liberal in ordering parties to produce documents. See id. at 43-48; Kobayashi, Minji soshö no shōten-Disukabari mondai o chushin ni [The Focus of Civil Litigation-Primarily Regarding the Discovery Issue], HoRITSU JiHO, Nov. 1983, at 17. The power 
vantages, of course, for defendants who control access to information, especially in complex economic cases like antitrust damage actions. ${ }^{103}$

Third, the government deliberately limits the number of lawyers. With few exceptions, one can become an attorney in Japan only by attending the Legal Training and Research Institute in Tokyo. ${ }^{164}$ The government controls the admission to this Institute, however, and has limited the number of entrants-and therefore the number of new lawyers-to about 500 annually. ${ }^{105}$ As a result, while over 350,000 lawyers practice in the United States, barely 11,000 practice in Japan. ${ }^{168}$

The consequences of this policy are predictable: a shortage of lawyers and high fee structures. ${ }^{1{ }^{187}}$ Most attorneys in Japan have chosen to practice in the metropolitan areas of Tokyo and Osaka. ${ }^{168}$ Thus, in many pro-

of the FTC to obtain evidence is also limited. See Haley, Antitrust in Japan: Problems of Enforcement, in Current Legal Aspects of Doing Business in Japan and East asia 121, 122 (J. Haley ed. 1978).

163. See Okujima, supra note 115 , at 15 (noting implications of lack of discovery for antitrust damage actions).

164. See T. Hattori \& D. Henderson, Civil Procedure in Japan § 2.02[3], at 2-14 to 2-15 (1983); Abe, Education of the Legal Profession in Japan, in LAW IN JAPAN, supra note 11, at 153, 158; Haley, supra note 13, at 385 . The exceptions to the requirement are discussed in Goto, Bengoshi no shikaku [The Qualifications of Lawyers], JrY Tu TE SEIGI, Feb. 1984, at 71.

165. See T. HATtori \& D. Henderson, supra note $164, \$ 2.02[2]$, at $2-13 \mathrm{n} .38$ (in the last year for which data were available, less than $2 \%$ of the nearly 30,000 applicants gained admission to Institute); Haley, supra note 13, at 385-86. But see Tsubota, supra note 153, at 9 (arguing that low pass rate on Institute entrance exam is not "deliberate government policy"). The per capita number of applicants who sit for this bar exam equivalent is higher than the per capita number of bar exam applicants in the United States. See Haley, supra note 13, at 385-86. Of each 500 admitted to the Institute, approximately 150 will take public service positions as judges or prosecutors rather than become lawyers. See Altschul, Japan's Elite Law Firms, INT'L FIN. L. Rev., June 1984, at 6, 7.

166. See T. HATTORI \& D. Henderson, supra note $164, \S 2.09$, at 2-45 \& n.159 (Japanese figures based on 1977 data; United States figures based on 1976 data).

167. A third effect is the use of attorney-substitutes. Due to the scarcity of lawyers, attorneys in Japan practice almost exclusively in the one area in which they have a monopoly: litigation. See Higuchi, Bengoshi ho to bengoshi gy'omu [The Lawyers' Law and Lawyers' Work], JIȲu TO sEIGI, Feb. 1984, at 4, 4; Tanaka, The Role of Law and Lawyers in Japanese Society, in THE JAPANESE LEgAL System, supra note 11, at 254, 257. For other "legal" services, Japanese generally turn to non-lawyer specialists. Tax work may be done by tax specialists, document work by judicial and administrative "scriveners," and patent work by patent specialists. The largest category of non-lawyer specialists may be those who study law in college and then either fail or do not take the entrance exam to the Legal Training and Research Institute. These are the people who will staff the law departments of the large Japanese corporations. See generally T. HATTORI \& D. Henderson, supra note $164, \$ 2.09$ (discussing non-lawyer specialists); Brown, A Lawyer by Any Other Name: Legal Advisors in Japan, in Legal Aspects of DoING Business IN JAPAN, supra note 11, at 201 (job outlines, member profiles, and geographic distribution of non-lawyer specialists); Stevens, Multinational Corporations and the Legal Profession: The Role of the Corporate Legal Department in Japan, in CuRRENT LEgal ASPECTS of DoIng Business in JAPAN AND EAST Asia, supra note 162, at 34, 35 (personnel of corporate legal departments in Japan are rarely attorneys); Tanaka, Quasi-Lawyers, in The JAPANese Legal SySTEM, supra note 11, at 563-65 (description of quasi-legal jobs in Japan). Moreover, a large percentage of litigants in Japan appear pro se. See T. HATTORI \& D. HENDERSON, supra note 164, $\$ 2.04$ at 2-23 n.60; Hattori, The Legal Profession in Japan: Its Historical Development and Present State, in LAW IN JAPAN, supra note 11, at 111, 146; Tanaka, The Role of Law and Lawyers in Japanese Society, supra, at 260.

168. See Tanase, The Urbanization of Lawyers and Its Functional Significance: Expansion in the Range of Work Activities and Change in Social Role, 13 L. JAPAN 20, 20-21 (B. Aronson trans. 
vincial towns and cities, attorneys are simply unavailable, ${ }^{169}$ and potential clients must incur considerable search costs to obtain representation. ${ }^{\mathbf{1 7 0}}$ Furthermore, the shortage of lawyers necessarily raises fees above the levels that would exist in the absence of barriers to entry in the profession. Reliable evidence is difficult to obtain, ${ }^{171}$ but fees in Japan may be high even by American standards. Japanese lawyers almost always use a twopart fee structure: an intitiation fee of approximately ten percent of the amount in controversy, paid as a nonrefundable retainer, ${ }^{172}$ and an additional fee of about fifteen percent of the value of a successful outcome. ${ }^{\mathbf{1 7 3}}$ Although this fee structure may resemble the usual American contingency fee of 30 percent, the similarity is deceptive. The initial fec is a percentage of the amount claimed - the amount demanded in the plaintiff's complaint or the value of the property at issue, rather than the amount successfully recovered. ${ }^{174}$ Moreover, because the initiation fee is not contingent and must be paid at the outset, an attorney takes a much smaller risk in exchange for his "cut" in the litigation and has the use of the money during the course of the representation. ${ }^{175}$

Fourth, the Japanese judicial system suffers from considerable delays. In part, these delays result from a shortage of judges. Despite the fact that

1980).

169. See Brown, supra note 167 , at 273.

170. See Stigler, The Economics of Information, 69 J. Pol. EcoN. 213, 216 (1961) (discussing relation betweeen scarcity and search costs).

171. Ishimura \& Kaminaga, Attorneys and Cases Involving Automobile Accidents, 9 L. JAPAN 83 (1976), suggests that considerable divergence exists in fee practices among Japanese attorneys. Thus, the following discussion should be taken in very general terms.

In comparing fee structures, one should be aware that Japanese litigants generally pay their own fees except in tort cases-in which a successful plaintiff may recover reasonable fees as part of the damages caused by the tort. See Saitō v. Watanabe, 1092 Hanrei jihō 34 (Japan Sup. Ct., Sept. 6, 1983); Hayashi v. Uchiyama, 23 Sai-han minshū 441, 444-45 (Japan Sup. Ct., Feb. 27, 1969); Harashima, Tökjō Chisai ni okeru songai baishōo gaku no jittai [Reality About Damage Awards by the Tokyo District Court], 431 JuRISUTo 235, 247-48 (1969); Tanaka \& Takeuchi, supra note 28, at 42-43.

Furthermore, one should note that some commentators have argued that a given piece of legal work requires less time in Japan than in the United States, so that the total fees paid for a given piece of work in Japan represent compensation for a smaller investment of time than they would in the United States. See Tsubota, supra note 153, at 10-11. Others have claimed that the quality of legal services provided in Japan is lower than in New York or London. See Altschul, supra note 165, at 7.

172. The percentage generally decreases as the claim increases. See J. Inokuma, Anata no höritsu SÖDan [Your Legal Consultation] 265 (1971) (5-10\%); H. Tanikawa, K. Iwaki, M. Miyahara \& A. Shirasaki, NichiJo seikatsu no hōritsu sōdan [Legal Consultation on Daily Living] 271 (1969) [hereinafter cited as H. Tanikawa]; Tanaka \& Takeuchi, supra note 28, at 42-43; Tsubota, supra note 153, at 10 .

173. See J. Inokuma, supra note 172 , at 265 (10-15\%); H. TANIKAWA, supra note 172, at 271; Tanaka \& Takeuchi, supra note 28 , at 42.

174. This fee structure operates, of course, as a disincentive to exaggerating one's damages. See Tsubota, supra note 153, at 10 .

175. Cf. R. POSNER, supra note 8, at 448-49 (contingent fee should compensate for loan of legal services). 
Japan has over half the population of the United States, ${ }^{176}$ Japan has fewer than two thousand judges of general jurisdiction, ${ }^{177}$ in contrast to the more than six hundred federal ${ }^{178}$ and six thousand state judges ${ }^{179}$ in the United States. ${ }^{180}$ Compounding the delay, Japanese civil procedure entitles litigants to a trial de novo on appeal, complete with new evidence, ${ }^{181}$ and a full review of legal issues at the Supreme Court. ${ }^{182}$ As a result, the average appealed civil case lasts more than five years, and cases extending over seven to ten years are not unusual. ${ }^{\mathbf{1 8 3}}$ Any plaintiff whose preference for money now rather than later exceeds the interest rate used by the court will necessarily be deterred from suing. ${ }^{184}$

\section{IMPLICATIONS FOR JAPAN}

These institutional barriers have profoundly affected attitudes toward litigation in Japan. The barriers do not, of course, prevent anyone who wishes to sue from suing. They do, however, dramatically alter a potential plaintiff's incentive to sue. Profit-maximizing victims of a cartel will assert a claim only if the likelihood of their success multiplied by the amount of their probable recovery exceeds the costs of asserting their claim. ${ }^{185}$ They

176. See The Hammond Almanac 600, 688 (M. Bacheller ed. 1980).

177. See T. HatTori \& D. Henderson, supra note $164, \S 3.03$, at 3-48 (1977 data; summary court judges excluded but, because of limitations of source, family court judges included).

178. 723 F.2d vii-xxxi (1984) (Article III judges only; senior judges excluded).

179. U.S. Bureau of Census, Statistical AbStract of THE UnITEd States 190 (104th ed. 1984) (1978 data).

180. According to one study, during the 1970's a typical federal district judge had a caseload of 325 cases, a typical California superior court judge had a caseload of 964 cases, and a typical Japanese trial court judge had a caseload of 1708 cases. See Haley, supra note 13, at 381.

181. See MINJI SOSHŌ но一 $\$ \S 360-392$; T. Hatrori \& D. Henderson, supra note $164, \S 8.02$. Roughly one-fourth of the district court judgments are appealed. See id. $\S 8.04 \mathrm{n} .9$.

182. See MinjI soshō Hō $\S \S 393$ to 409-3; T. HatTori \& D. Henderson, supra note 164, $\S$ 8.03. The right to appeal to the Supreme Court exists for cases begun in the district courts but not for those begun in the summary courts. Roughly one-third of all high court judgments are appealed to the Supreme Court. See id., $\$ 8.03[2]$, at 8-15 n.78.

183. Shapiro, supra note 11, at 25, 56; Tanaka, Delays in Court Proceedings, in The JaPANese LEGAL SySTEM, supra note 11, at 475, 476-77. These data appear roughly comparable to the data on antitrust cases in the United States-thought to be among the most protracted cases. See Posner, supra note 65 , at 377 .

184. Japanese courts assess interest at the statutory rate of 5\%. MiNPo $\S \S 404,419$; see, e.g., Saito v. Watanabe, 1092 Hanrei jihō 35, 36 (Japan Sup. Ct., Sept. 6, 1983) (assessing interest); Yamada v. Keihin Kyūkō Dentetsu, K.K., 466 Hanrei taimuzu 65, 68 (Tokyo High Ct., May 11, 1982) (same).

Litigation in Japan proceeds according to the continental system of disconnected trials. See T. HATTORI \& D. HENDERSON, supra note $164, \S 7.04[2]$, at 7-50 to 7-51. At least in theory, this system should not increase the amount of time between the complaint and the judgment, so long as the number of cases and judges remains fixed. Rather, under the common law system of continuous trials, the plaintiff will wait longer before going to trial, while under the continental system the plaintiff will go to trial sooner but find that the actual trial takes more time. Disconnected trials should increase delays only if time is wasted through the repetitious re-learning of cases by the personnel involved. But see Haley, supra note 13, at 381 (form of trial in Japan aggravates delay).

185. If a successful party may recover such costs as attorneys' fees, then appropriate adjustments 
will choose to sue rather than to settle only if the difference between their expected discounted recovery and their expenses is greater through litigation than through settlement. ${ }^{186}$ As $K a i$ and Sato demonstrate, the Japanese rules regarding the "pass-on" defense, damages, and discovery all reduce the likelihood of successful recovery. The lack of a treble damage provision reduces the amount of the probable recovery from that offered American plaintiffs. ${ }^{\mathbf{1 8 7}}$ The absence of class actions, the existence of a pass-on defense, and the shortage of attorneys all raise the cost of litigation. ${ }^{188}$ The cumulative effect of these barriers is to reduce drastically the number of cases in which plaintiffs find it profitable to sue. Because they make litigation a less credible threat than otherwise, these barriers also reduce the amounts that victims will recover through settlement.

By removing virtually all financial incentives to bringing an antitrust suit, these barriers help to perpetuate the nonlitigious ethos. Because of the barriers, few victims of price-fixing agreements will need to choose between the security of the orthodox nonlitigious ethos and financial gain-for the orthodox option will almost always also be the profitable option. As a result, the barriers help to ensure that would-be litigants live in a world in which few people sue, a world which confirms rather than threatens the ethos condemning litigation as selfish and un-Japanese.

Yet if the barriers to litigation shape Japanese attitudes toward litigation, their implications extend beyond this conceptual level. Economically, the barriers to private antitrust suits have introduced the inefficiencies associated with cartels everywhere; politically, the barriers to this and other litigation have helped to ensure the continued legitimacy of bureaucratic rule.

\section{A. Economic Implications}

The economic costs to Japan of maintaining these institutional barriers to private suits have been high indeed, for virtually no other deterrents to price-fixing exist. Japan has, in other words, effectively removed almost all disincentives to cartelization. A business executive considering fixing prices in Japan has practically nothing to lose.

Because of the absence of private suits, Japan has in effect entrusted the entire task of enforcing the Antimonopoly Act to the FTC. ${ }^{189}$ Yet perhaps

to this formula become necessary. See supra note 45 . Whether a successful plaintiff under Antimonopoly Act $\$ 25$ may recover attorneys' fees (on the ground that an antitrust violation resembles a tort) is unclear. See supra note 171.

186. See Landes, An Economic Analysis of the Courts, 14 J.L. \& Econ. 61, 101 (1971)

187. Although the pass-on defense does not reduce the aggregate damages recoverable, it may reduce the amount that a given plaintiff may recover.

188. The absence of discovery may, however, reduce the cost of litigation.

189. See Kikuchi, supra note 157 , at 29-30. 
due to its relative lack of support in the legislature and the rest of the bureaucracy, ${ }^{100}$ the Commission can do little to carry out its task. Al. though the Commission can initiate criminal prosecutions, that threat will deter few entrepreneurs. Since the oil cartel criminal cases it initiated in $1974,{ }^{191}$ the Commission has failed to bring a single prosecution. ${ }^{192}$ The Commission does bring administrative suits to obtain consent decrees ${ }^{193}$ and cease-and-desist orders. ${ }^{194}$ But these measures merely require a cartel that has been discovered to disband-they do nothing to penalize pricefixers.

The only real deterrent at the FTC's disposal is the surcharge of 0.5 to 2 percent of a firm's gross earnings from a cartel. ${ }^{195}$ Even this measure, however, appears inadequate. To date, few writers have analyzed the deterrent value of the surcharge. No comprehensive empirical studies exist, and because the two-percent-of-gross-revenue formula bears no consistent relation to the profits a would-be price-fixer could earn by joining a cartel, no theoretical analysis is possible. What analysis there is, however, suggests that the surcharge is generally less than the harm caused by a cartel. ${ }^{198}$ In any case, the probability that a cartel would be assessed the surcharge is very low. From the time the surcharge provision was enacted in $1977^{187}$ to March 1983, the FTG brought only 32 surcharge actions. ${ }^{198}$ On the basis of this minimal chance of detection alone, the surcharge is

190. See E. Hadley, supta note 31 , at 445 ; D. Henderson, Foreign Enterprise in Japan 150 (1973); Note, supra note 33, at 1066-68.

191. See supra note 65.

192. Why the FTC has brought so few criminal prosecutions is not clear. Various Japanese commentators have argued that Japan has not enforced the Antimonopoly Act aggressively because cartels in fact cause less harm in Japan than elsewhere. See, e.g., Amaya, Wa no rinri, supra note 24, at 176 (American-style Antimonopoly Act, with its prohibition of cartels, fundamentally unsuited to grouporiented Japanese culture). This theory probably reflects a belief that "cooperative" behavior like cartelization is well-suited to a "consensual" and "harmonious" society like Japan. See infra pp. 637-38. A more plausible reason is that some Japanese perceive price-fixing to be a relatively innocuous crime for which criminal sanctions are inappropriate. But see supra p. 611 (such perception should not be exaggerated).

The FTC may also consider criminal prosecutions to be an inefficient use of its resources. Because of the stigma of conviction, a firm is more likely to contest a criminal prosecution than an administrative action. In order to conserve its resources, the Commission may concentrate its efforts on those actions that firms are least likely to contest vigorously. See R. PosNer, supra note 8 , at 474-78. Note, however, that the resources invested in the prosecution will primarily be those of the Ministry of Justice rather than the FTC.

193. See Antimonopoly Act, supra note $34, \S \S 48,53-3$.

194. See id. $\$ 54$.

195. See id. §7-2.

196. See Okujima, supra note 115 , at 7 .

197. Law No. 63 of 1977.

198. The total assessed surcharge was $7,404,750,000$ yen, or about $\$ 35,260,000$. See 1983 KÖSEI

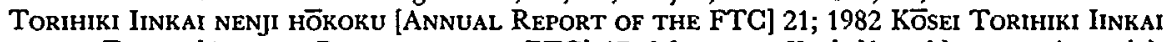
NENJi HŌKOKU [ANNUAL REPORT OF THE FTC] 17; Motonaga, Kachōkin seido no genjo to doko [The Status and Direction of the Surcharge System], 751 JuRIsuro 43, 46 (1981). 
almost certainly far less than the optimal deterrent: the cartel's social harm divided by the probability of discovery. ${ }^{109}$

This dearth of enforceable deterrents to price-fixing has apparently led to exactly the consequences one would expect: a "cooperative" economy characterized by widespread cartelization. ${ }^{200}$ As noted earlier, cartels transfer wealth from purchasers to sellers, increase the price of the cartelized good above its marginal cost while decreasing its supply and increasing the demand for its substitutes, and increase the cost of producing the cartelized good. ${ }^{201}$ Quantitative economic analysis is beyond the scope of this Article, but the data suggests that despite the remarkable performance of the Japanese economy in many sectors, cartels have taken their toll. "The Japanese economy has borne," as one Brookings Institution study concludes, "significant costs in the form of allocative inefficiency and diversion of rivalry into costly nonprice forms. We can detect no corresponding gains."202

\section{B. Political Implications}

The consequences of the barriers to litigation have been not only economic but political. By decreasing the incidence of litigation, the barriers have helped to perpetuate the myth of Japan as a consensual and harmonious society. And it is in part by that consensual myth that the bureaucracy has legitimated its dominant role in Japanese society.

\section{The Consensual Myth and the Bureaucracy}

The nonlitigious ethos in Japan is part of a larger tradition in which Japanese individuals have perceived their society to be uniquely consensual and harmonious. ${ }^{203}$ Whether Japan is in fact unusually consensual or harmonious is not the issue here. ${ }^{204}$ What matters to this Article is that

199. See supra pp. 605-06.

200. See Caves \& Uekusa, supra note 32, at 491-92; cf. E. HADLEY, supra note 31, at 357-89 (discussing cartels in Japan); K. YamamuRA, supra note 35, at 39-86 (discussing historical development of "pro-monopoly" policy).

201. See infra p. 612 .

202. Caves \& Uekusa, supra note 32, at 522. But see Rotwein, Economic Concentration and Monopoly in Japan-A Second View, 36 J. AsIan Stud. 57, 75 (1976) (Japanese cartel policy "may contribute to mounting problems in the future," but cartels to date have often been ineffective).

203. The Japanese term for harmony is "wa," which Japanese commentators have often described as a Japanese characteristic. See, e.g., Amaya, Wa no rinri, supra note 24, at 182 (concept of "wa" is fundamental to understanding group-oriented character of Japanese culture); Nakamura, Basic Features of the Legal, Political, and Economic Thought of Japan, in THE JAPANESE Mind, supra note 17, at 143, 145-48 (relating "spirit of harmony" to Japanese concept of law).

204. See Mouer \& Sugimoto, Theories of Japanese Culture: Reply, 24 CuRRENT ANTHROPOLoGY 659 (1983) (criticizing "consensus model" of Japanese society); Najita, Introduction: A Synchronous Approach to the Study of Conflict in Modern Japanese History, in ConfLICT IN MODERN JAPANESE History 3, 9 (T. Najita \& J. Koschmann eds. 1982) (criticizing description of Japan as 
the Japanese see their world as one that successfully promotes those values. As one prominent MITI official wrote in 1980:

Both in the past and in the present, the fundamental social unit in Japan has been not the atomistic individual but the molecular group. ... The individual experiences life as an organic member of the group, and the fundamental ethic within the group is, whether in the Shōtoku ${ }^{205}$ Cabinet or the Suzuki Cabinet, that of "harmony."206

This perception of harmony is crucial, for it plays a central part in legitimating bureaucratic rule in Japan.

Although structured as a parliamentary democracy, modern Japan is largely governed by an elite and fundamentally nondemocratic bureaucracy. ${ }^{207}$ The ministries rather than the legislature draft the laws and determine basic national policies for the future. Contrasting the Japanese legislature with the bureaucracy, political scientist Chalmers Johnson describes a "separation . . . between reigning and ruling, . . . between the majority party and the mandarinate-and, in the last analysis, between authority and power."208 The power of MITI and the Ministry of Finance to direct the economy is perhaps the most visible, and certainly the most widely discussed, aspect of bureaucratic rule. Indeed, from these ministries derives the caricature of "Japan, Inc." Yet the allocation of political power takes place in much the same manner at local levels. As any American who has lived in Japan for any length of time knows, local bureaucrats can act in ways at least as intrusive as those of MITI. ${ }^{200}$

Moreover, the Japanese bureaucracy has largely exercised its power without the constraints on bureaucratic discretion imposed by representative or judicial mechanisms. A ministry may consult repeatedly with an industry it regulates, and may meet with members of the academic community or even the public. Yet the ministry itself determines with whom it

consensual); Silberman, The Bureaucratic State in Japan: The Problem of Authority and Legitimacy, in Conflict in MODERN JAPANese History, id., at 226, 229 ("Japan's experience after 1868 embodies the major paradoxes of the modern capitalist state: centralized power along with unruliness").

205. Shōtoku Taishi served as regent to the Japanese empress from 593 to 622 A.D. See M. Hane, Japan: A Historical. Survey 35 (1972).

206. Amaya, Wa no rinri, supra note 24 , at 182 (translation by J.M. Ramseyer; emphasis in original).

207. See generally D. HENDERSON, supra note 190, at 166, 195-215 (description of bureaucratic rule; bureaucracy largely immune from judicial review); C. JoHnson, supra note 33, at 22 ("decision-making is centered in . . . an elite bureaucracy" in "plan-rational" societies like Japan); Johnson, Japan: Who Governs? An Essay on Official Bureaucracy, 2 J. JAPANese STud. 1, 28 (1975) (Japanese bureaucracy holds "an ascendant position").

208. C. JoHNSON, supra note 33 , at 35 .

209. See Young, supra note 79, at 931-32 (discussing administrative guidance by local governments); Hayashi, supra note 88,1223 TOKI No HŌREI at 54. 
will consult and what it will discuss. ${ }^{210}$ To the extent the ministry compromises its stand on an issue, it generally does so only to obtain the acquiesence of the industry regulated, not because of any representative process within the bureaucratic apparatus. Nor does judicial review of bureaucratic action exist to any significant extent in Japan: Japanese courts have invoked standing, justiciability, and administrative discretion to eliminate most judicial review of administrative action. ${ }^{211}$

\section{Litigation and Legitimacy}

Some of the institutional barriers to litigarion forthrightly protect this bureaucratic prerogative. The various obstacles inhibiting legal challenges to administrative action are perhaps the most obvious examples. ${ }^{212}$ The Japanese class-action and discovery rules, however, also exemplify such barriers. The class-action provisions frustrate challenges to bureaucratic policies of the sort seen in Kai and Sato. The ineffective discovery mechanisms hamper parties without access to information-more likely to be those outside the bureaucratic and economic elite than within it.

The political implications of other institutional barriers to litigation are less explicit, since these barriers may reduce the utility of the courts for everyone in society and curtail all litigation, not just that posing a direct challenge to the bureaucracy. Leading business firms can be victims of price-fixing arrangements as often as consumers are. Yet the "pass on" defense and the insistence on a precise proof of damages will reduce those firms' ability to recover their losses. The shortage of judges forces the economic elite to queue for judicial services like everyone else, ${ }^{213}$ and the shortage of attorneys raises the price of legal services to all. Indeed, to the

210. See generally C. JohNson, supra note 33, at 47-50 (government policy panels known as "shingikai" often have limited input, if any, while outsiders are ignored); $c f$. Young, supra note 79, at 938-41 (parties regulated, though not the public, may have considerable role in formulation of policy). As of 1977, representatives of consumers made up one percent of the membership of the shingikai. See Miyamoto, supra note 67, at 78.

211. See, e.g., D. HENDERSON, supra note 190, at 200-06 (vast administrative powers "are little affected by legalities"); Lury, Japanese Administrative Practice: The Discretionary Role of the Japanese Government Official, 31 Bus. LAw. 2109, 2110-21 (1976) (broad phrasing of statutes permits nearly "free" administrative discretion); Upham, supra note 30, at 235-44 (doctrines of ripeness and standing are major obstacles for environmental claims); F. Upham, Law and Social Conflict in Contemporary Japan VI: 10-22 (1984) (unpublished manuscript) (discussing doctrines of justiciability, standing, and administrative discretion). Judicial review is further hampered by the limited nature of the sanctions that a Japanese court may impose, see Haley, Sheathing the Sword of Justice in Japan: An Essay on Law Without Sanctions, 8 J. JAPANeSE Stud. 265 (1982), and by the limitations on the availability of equitable relief, see Upham, supra note 30, at 226, 228-34 (difficulties of obtaining injunctive relief in environmental cases). But see Young, supra note 79, at 958-80 (arguing that limitations on judicial review in Japan have sometimes been exaggerated).

212. See sources cited supra note 211.

213. Judicial delays would damage the economic elite less than other members of society only if the elite discounted money at a lower rate than the public - an unlikely proposition. 
extent law protects existing property rights, those with the most property may have the greatest need for courts and suffer the greatest harm from any general barriers to litigation. ${ }^{214}$

The political implications of these more broad-ranging barriers to litigation are not, therefore, immmediately apparent. Instead, these implications become clear only in light of the relation between litigation and the Japanese consensual myth. Litigation is a public and contentious exercise. It forces parties to make clear, conflicting claims, and brings to the surface disputes among individuals and between social groups. ${ }^{215}$ As a result, it necessarily provides an individual with "empirical" evidence of the tenuous character of the Japanese consensus. Litigation thus confronts the individual as a threat to his or her vision of Japan as a consensual society. On the other hand, to the extent that individuals internalize the nonlitigious ethos-to the extent that the ethos prevents them from suing-the ethos destroys that "empirical" evidence and helps to ensure the continued plausibility of the consensual myth. By making it unprofitable to sue, in other words, the institutional barriers help to perpetuate the nonlitigious ethos; by so doing, they decrease the incidence of litigation and help to insure the viability of the consensual myth.

This consensual myth is important because of the role it plays in legitimating bureaucratic rule. Legitimacy, in the words of Frankfurt School ${ }^{\mathbf{2 1 6}}$ theorist Jürgen Habermas, represents "a political order's claim to be recognized as right and just." ${ }^{217}$ In Japan, where legitimate authority is premised on strongly held democratic principles, a major task of a legitimating myth is to resolve, at an ideational level, the contradiction between those democratic principles and the fact of nondemocratic bureaucratic rule. ${ }^{218}$ The consensual myth mediates this contradiction by positing a popular consensus which purportedly defines the contours of bureaucratic action. $^{219}$ The public perceives bureaucratic rule as consistent with

214. For example, Haskell, Litigation and Social Status in Seventeenth-Century New Haven, 7 J. LEGAL STUD. 219, 238-39 (1978), found a strong correlation between social status and the use of the courts. Haskell suggests "that the very nature of law ensures that high status persons appear more often as plaintiff than as defendant." Id. at 238.

215. There is, of course, a risk to the elite in making litigation relatively unavailable. Aggrieved parties may then take their disputes "to the streets" and make the existence of their grievances harder to deny than if they had litigated their claims. Environmental pollution disputes in Japan, for example, have involved a combination of litigation with such out-of-court demonstrations. See Upham, Litigation and Moral Consciousness in Japan: An Interpretive Analysis of Four Japanese Pollution Suits, 10 L. \& Soc'y REv. 579 (1976).

216. See generally T. BotTomore, The Frankfurt School (1984) (overview of the Frankfurt School).

217. J. Habermas, Communication and the Evolution of Society 178 (T. McCarthy trans. 1979).

218. Cf. M. Urban, The Ideology of Administration 5 (1982) (ideology mediates at sym. bolic level between democratic norms and class structure).

219. Indeed, some Japanese courts have even determined the propriety of government actions by 
democratic principles, in other words, because it perceives that rule as directed and constrained by a broadly based consensus on major issues.

In thus reconciling the existing allocation of power with the dominant political metaphysic, the consensual myth reduces the extent to which individuals feel estranged from the state. Minimizing that subjective alienation is crucial to maintaining the stability of the state. As anthropologist Clifford Geertz explains, if "a state [is] to do more than administer privilege and defend itself against its own population, its acts must seem continuous with the selves of those whose state it pretends it is, its citizens-to be, in some stepped-up, amplified sense, their acts."220 The consensual myth reduces the estrangement of the individual from the state by enabling individuals to see themselves as governed in a manner consistent with their democratic values; the myth accomplishes this by enabling them to see themselves as part of a society characterized by a broadranging consensus and governed by a bureaucracy guided by that consensus. Through the consensual myth, in short, individuals perceive that bureaucracy as their bureaucracy. The consensual myth creates, in Geertz's words, "a collective subject to whom the actions of the state can be internally connected, . . . an experiential 'we' from whose will the activities of government seem spontaneously to flow."221

To the extent that belief in the consensual myth remains plausible, the Japanese bureaucracy can claim, by virtue of its rationality and expertise, to be the instrument best able to implement that consensus. ${ }^{222}$ In terms of rationality, the Japanese upper civil service resembles the archetype of Max Weber's efficient bureaucracy: an institution "superior to any other form in precision, in stability, in the stringency of its discipline, and in its reliability." 223 In terms of intellectual ability, the upper civil servants in Japan have few equals. MITI and the Ministry of Finance consistently recruit the brightest graduates of the most highly regarded universities in Japan, and promote within their ranks only the most outstanding individuals. ${ }^{224}$

discussing whether the actions accorded with a societal consensus, see Young, supra note 79, at 966-68.

220. C. GeERTZ, supra note 9, at 317 (italics in original).

221. Id. at 240 .

222. Cf. Frug, The Ideology of Bureaucracy in American Law, 97 HARv. L. REv. 1276, 1282-83 (1984) (expertise and professionalism often accepted as justification for bureaucratic discretion); Stewart, The Reformation of American Administrative Law, 88 HARV. L. REv. 1667, 1678 (1975) (given ascertainable goals, expertise solves problem of administrative discretion).

223. M. Weber, The Theory of Social and Economic Organization 337 (A. Henderson \& T. Parsons trans. 1947). See J. Habermas, Toward a Rational Society 82-83 (J. Shapiro trans. 1971) (bureaucracy rationalizes conditions of life); M. URBAN, supra note 218, at 24-25 (discussing "cult of expertise").

224. See, e.g., C. JoHNSon, supra note 33, at 39, 57-66 (entrance into and promotion within the ministries largely dependent on competitive performance on "incredibly competitive" examinations); 
Nevertheless, the bureaucracy's claim that its legitimacy derives from the public consensus depends on the continuing existence of a widely shared vision of the commonweal-a collective vision that remains ostensibly independent of the bureaucracy and determines the boundaries of bureaucratic activity. In a world perceived as pluralistic, the bureaucracy can point to no consensus that it can claim to implement and by which it can claim to be restrained; in a pluralistic world, MITI can articulate no consensus to justify its practice of independently determining the content of national goals and the means by which it will pursue them. Legitimating bureaucratic domination would instead need to depend on alternative myths.

In the absence of a consensual myth, alternative legitimating models would probably involve either an increased legislative role or a new mode of bureaucratic decisionmaking. ${ }^{225}$ Thus, the Japanese Diet might become the arbiter of the public interest. Because the Diet formally represents the locus of popular sovereignty, its decisions, if made according to democratic procedures, acquire legitimacy sui generis. In providing the boundaries of bureaucratic action, those legislative decisions, because themselves legitimate, would in turn legitimate bureaucratic action. The bureaucracy could also acquire legitimacy by introducing representational mechanisms into the bureaucratic apparatus itself. As in the "interest-balancing" model of American administrative law, ${ }^{228}$ the Japanese bureaucracy would grant to various "interest groups" the right to participate in the processes by which it determines and implements policy. ${ }^{227}$ The arguably democratic character of this decisionmaking process would thereby legitimate bureaucratic action.

Under either an increased legislative role or the interest-balancing model, however, bureaucratic discretion necessarily contracts. Under

E. VOGEL, supra note 2, at 54-61 ("Leading bureaucrats invariably have attended the best universities and have risen through the ranks in a carefully prescribed fashion."); see also Silberman, supra note 204, at 251-53 (bureaucratic authority based on "monopoly over expertise"); $c f$. Smith, "Merit" as Ideology in the Tokugawa Period, in Aspects of Social Change In Modern JaPan 71 (R. Dore ed. 1967) (discussing relation between bureaucratic legitimacy and meritocratic ideology in premodern Japan).

225. In addition, of course, modern bureaucracies may claim to be repositories of a value-free expertise that itself establishes the parameters of bureaucratic action. "[T] effectiveness functions as a moral fiction," Alasdair MacIntyre writes, for "[b]elief in managerial expertise is . . . very like what belief in God was thought to be by Carnap and Ayer[,] . . . the illusion of a power not ourselves that claims to make for righteousness." A. MAcINTYRE, AFTER VIRTUE 76, 107 (2d ed. 1984) (italics omitted).

226. See generally Stewart, supra note 222, at 1723-90 (developing model of "interest representation"). This would represent a greatly expanded role for the shingikai, see supra note 210 .

227. Cf. Frug, supra note 222, at 1283-84 (discussing claim that "either interest-group politics or market forces intervene to discipline bureaucratic management"). This process, of course, is known in sociological circles as "co-optation." See Selznick, Foundations of the Theory of Organization, 13 AM. Soc. REv. 25, 34-35 (1948). 
either formula, parties outside of the bureaucracy acquire a role in the process by which national policy is determined. In effect, the focus of legitimation shifts from a teleological argument to a procedural one. $\mathrm{Bu}-$ reaucratic power becomes legitimate not because it promotes the goals embodied in a mythical and indefinitely malleable consensus, but because of the concrete manner in which the legislature or the bureaucracy determines the course of bureaucratic action. ${ }^{228}$

At present, the Japanese bureaucracy has no access to such alternate legitimating models. In large part, the Japanese bureaucracy continues to determine policy independently of the Diet and without making use of representational mechanisms. Bereft of the consensual myth, the Japanese bureaucracy would be deprived of a primary means of reconciling bureaucratic rule with democratic principles. Only in this context does the full importance of the barriers to litigation become clear. By discouraging litigation and preserving the nonlitigious ethos, the barriers help to perpetuate the consensual myth. Only through that consensual myth is the Japanese democratic ideology reconciled with the existing distribution of power; ${ }^{229}$ only through that reconciliation do individuals perceive the Japanese state as their state; and only through that subjective identification with the state do individuals perceive the status quo as legitimate.

\section{ConClusion}

The institutional barriers to litigation in Japan have, it appears, all but eliminated private antitrust damage suits. The Japanese have paid dearly for this, for the dearth of private antitrust litigation has removed all effective deterrents to price-fixing. If the economic consequences of the barriers have been severe, the political consequences have been no less farreaching. Litigation is relatively scarce in Japan, and that scarcity is due both to institutional barriers to litigation and to a nonlitigious ethos perpetuated in part by those barriers. In turn, however, the scarcity of litigation has helped to make plausible the myth of Japan as a consensual and harmonious society, and that consensual myth has played a central part in legitimating the present form of bureaucratic domination.

The current obsession with the concept of "culture" has been misleading primarily because most observers of Japanese law have tended to divorce culture from the structure of Japanese society and the individuals who live within it. As "an ordered system of meaning and of symbols,"230

228. Cf. Kelly, Who Needs a Theory of Citizenship?, Daedalus, Fall 1979, at 21, 25 (contrasting "telocratic" (purpose-governed) and "nomocratic" (rule-governed) legitimations).

229. See C. GEERTZ, supra note 9, at 332 (legitimation is the "reconciliation of [the] political metaphysic with the actual distribution of power").

230. Id. at 144. 
however, culture both reflects social structures and is reflected in them. Japanese find their culture compelling because the social structures within which they live help to ensure that they behave according to cultural norms; they find those structures legitimate because of the explanatory-and justificatory-power of their culture. As Americans tirelessly point out, one cannot understand structures like the Japanese legal system without understanding the culture which explains why these structures are as they are. Yet neither can one understand components of that culture, like attitudes toward the legal system, without examining the institutional arrangements that help to perpetuate that culture.

In effect, the current discussion of culture fails to relate the concept of culture to the subjective calculus by which individual Japanese make decisions. To say that Japanese behave the way they do because of their culture ignores the process by which culture is transformed into action. An individual's culture provides him or her with psychic rewards for conforming his or her behavior to cultural norms and with psychic costs for doing otherwise, and this psychic calculus takes on a social dimension through communal action: acceptance and praise for appropriate behavior, rejection and scorn for any deviation.

An individual will, of course, weigh these culturally determined rewards and costs in deciding what to do in a given situation. Yet he or she will also consider other factors, for the structures of a society will provide the individual with a set of rewards and costs independent of the cultural calculus. Cultural norms may indicate, for example, that it is wrong to pick pockets or wrong to sue. Yet, if few pickpockets are punished or if many plaintiffs collect larger amounts through litigation than they could through settlement, individuals will find it financially profitable to violate those norms. Such a divergence between the cultural and structural calculi will be inherently unstable. ${ }^{231}$ If structural rewards are high enough to induce large numbers of people to violate cultural norms, the rest of society will begin either to perceive such behavior as acceptable or to modify those structures and remove the rewards for engaging in the culturally unacceptable behavior. That instability, however, is in large part absent from the Japanese legal world. For there is, in Japan, an essential congruence between the cultural and structural calculi regarding litigation: If it is wrong and un-Japanese to sue, it is also unprofitable.

Unfortunately, too many Americans have remained oblivious to Japanese social structures and the subjective calculi of individual Japanese. Too many commentators on Japanese law have done little more than repeat various truisms on culture-praising the nonlitigious ethos without

231. See id. at $142-46$. 
asking why it persists and accepting the consensual myth without examining the role it plays in the allocation of wealth and power in Japanese society. Culture, it seems, has become an analytical "Serbonian bog ... where [scholars] whole have sunk." 232

There has been, moreover, an ingenuous gullibility in much of this American analysis. Many observers of the modern Japanese legal world have returned from their excursions and done little more than describe a harmonious society united behind economic growth, a world where individuals live for the group, a country that sacrifices private gain for the commonweal. Whatever some Japanese commentators may say, however, surely the acquiescence of powerless groups is not necessarily evidence of "consensus," 233 just as the absence of litigation is not evidence of "harmony." One simply cannot take such popular Japanese explanations at face value, for comparative law is instead a bit like a good Hitchcock: Things are rarely what they are perceived to be. The task of comparative law is not merely to describe these widely held perceptions, but to look behind them, to explore the ways in which those perceptions themselves shape the worlds of which they are a part. For even if the popular Japanese myths about their polity do not accurately describe Japan, they always tell us how the Japanese perceive Japan. And ultimately, these popular Japanese myths may themselves shape the Japanese economic and political order.

232. J. Milton, Paradise Lost Book II, 1l. 592-94 (S. Elledge ed. 1975) (2d rev. ed. London

233. See J. Gaventa, Power and Powerlessness: Quiescence and Rebellion in an APPaLACHIAN VALLEY 4 (1980) ("[I]n situations of inequality, the political response of the deprived group or class may be seen as a function of power relationships, such that power serves for the development and maintenance of the quiescence of the non-elite."). 


\section{The Yale Law Journal}

Volume 94, Number 3, January 1985

\section{Mark E. Haddad Editor-in-Chief}

Beth S. Brinkmann

Julia E. Guttman

Peter D. Keisler Sarah Korn

Robert A. Long Note Editors
Amy L. Henrich

Managing Editor

Lynn A. Baker

Anita Bernstein

Ronald D. Lee

Howard M. Shapiro

William M. Treanor

Article $\mathcal{F}^{\circ}$ Book Review Editors

\section{Senior Editors}

Pauline E. Calande

Sharon A. Hooper

Niki Kuckes

John R. Low-Beer
David A. Martland

Emily S. McMahon

John B. Sandage

Gene C. Schaerr

Paul Schwartz
Gene B. Sperling

Peter P. Sivire

Stephen H. Willard

Wendy A. Wolf

\section{Editors}

Robert S. Adelson

Thomas P. Arden

David M. Aronowitz

Patrick A. Broderick

Kenneth Ghristman

Stephen M. Cutler

David R. Dow

Deborah D. Dupire

Peter R. Ezersky

Sarah B. Gordon

Rosemary Herbert

Alan Hirsch

Kenneth G. Johnsen

Howard Kruse

Ronald J. Kuerbitz

Ghristopher C. Magorian
David C. Marcus

Kathleen L. Roin Reva Siegel

A. Glayton Spencer

W. Danforth Townley

Stephen A. Warnke Jack Wenik Songyi Zhang

Business Manager: Pamela Standish Editorial Assistant: Rosemary B. Carey

\section{Student Contributors to this Issue}

Anita Bernstein, Executive Targeting of Congressmen as a Violation of the Arrest Clause

Gene G. Schaerr, The Gellophane Fallacy and the Justice Department's Guidelines for Horizontal Mergers

William Michael Treanor, The Origins and Original Significance of the Just Compensation Clause of the Fifth Amendment 